\title{
Endothelial Dysfunction in the Apolipoprotein E-deficient Mouse: insights into the influence of diet, gender and aging
}

\author{
Silvana S Meyrelles ${ }^{1}$, Veronica A Peotta ${ }^{2}$, Thiago MC Pereira ${ }^{3}$ and Elisardo C Vasquez ${ }^{1,4^{*}}$
}

\begin{abstract}
Since the early 1990s, several strains of genetically modified mice have been developed as models for experimental atherosclerosis. Among the available models, the apolipoprotein E-deficient (apoE ${ }^{-1}$ ) mouse is of particular relevance because of its propensity to spontaneously develop hypercholesterolemia and atherosclerotic lesions that are similar to those found in humans, even when the mice are fed a chow diet. The main purpose of this review is to highlight the key achievements that have contributed to elucidating the mechanisms pertaining to vascular

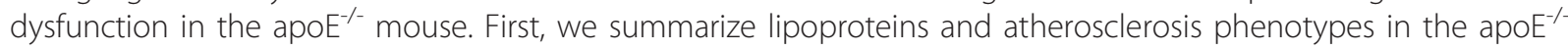
mouse, and then we briefly discuss controversial evidence relative to the influence of gender on the development of atherosclerosis in this murine model. Second, we discuss the main mechanisms underlying the endothelial dysfunction of conducting vessels and resistance vessels and examine how this vascular defect can be influenced by diet, aging and gender in the apoE $\mathrm{E}^{-/-}$mouse.
\end{abstract}

Keywords: apoE, hypercholesterolemia, atherosclerosis, endothelial dysfunction, oxidative stress, gender

\section{Background}

Because mice are easily bred, have a short generation time and because of the availability of inbred strains, many of which have interesting heritable phenotypes, they are ideal models for the study of genetic contributions to disease [1]. The major disadvantage of the mouse model is its small size, which makes it relatively difficult to perform neural and hemodynamic measurements; however, in our and other laboratories the limitations of the mouse have been overcome through advances in surgical techniques (e.g., vascular catheterization and nerve recording) and in diagnostic imaging methods.

Due to the progressive advancement of molecular biology techniques, it is possible to knockout and restore endogenous genes or to add exogenous genes into the mouse allowing the development of mouse models for human diseases [2-8]. In this brief review, we focus on the apolipoprotein E-deficient $\left(\mathrm{apoE}^{-1-}\right)$ mouse,

\footnotetext{
* Correspondence: evasquez@pq.cnpq.br

'Departament of Physiological Sciences, Health Sciences Center, Federal

University of Espirito Santo, Vitoria, ES, Brazil

Full list of author information is available at the end of the article
}

which is considered the best available model for human lipoprotein disorders and atherosclerosis $[9,10]$. Specifically, we discuss the main mechanisms underlying endothelial dysfunction in the $\mathrm{apoE}^{-/-}$mouse and examine how this vascular defect can be influenced by diet, aging and gender.

\section{Lipoproteins and Atherosclerosis Phenotypes Murine plasma lipid profiles}

The lipid profiles of mice and humans differ greatly. Humans carry approximately $75 \%$ of their total plasma cholesterol (PC) on the atherogenic low-density lipoprotein (LDL). Mice naturally carry most of their PC on the antiatherogenic high-density lipoprotein (HDL, $70 \mathrm{mg} /$ dL) $[1,3,11,12]$. Normal mice have total PC levels of approximately $80 \mathrm{mg} / \mathrm{dL}$ and are highly resistant to atherosclerotic lesions. An exception is the C57BL/6J (C57) mouse strain when it is challenged with a special atherogenic diet $[3,13,14]$. Interestingly, in this mouse strain, males and females that are fed a diet of normal chow do not differ in their HDL-lipid levels, but females demonstrate a drop $(\sim 50 \%)$ in their HDL levels when fed an atherogenic diet. Males appear to maintain high 
HDL levels due to their secretion of testosterone [14]. Thus, for the analysis of lipid metabolism and atherosclerosis in mouse models, diet and gender should be taken into account.

\section{Plasma lipid profiles and atherosclerosis in the apolipoprotein E-deficient mouse}

In 1992, two different groups simultaneously created the first gene-targeted murine model of atherosclerosis by disrupting the antiatherogenic apolipoprotein $\mathrm{E}$ (apoE) gene that is involved in cholesterol metabolism $[2,3]$. The inactivation of the apoE gene is achieved by homologous recombination in mouse embryonic stem cells, usually in a C57 genetic background, to produce apolipoprotein E-deficient $\left(\mathrm{apoE}^{-/-}\right.$) or knockout (apoE KO) mouse. The apoE $E^{-/-}$mouse is the most widely used of the available murine models, and it was the first model to develop vascular lesions that are similar to those observed in humans. ApoE is a glycoprotein with a molecular weight of approximately $34 \mathrm{kDa}$, which is synthesized in the liver, brain and in macrophages and it is a constituent of chylomicrons and their remnants, very-low-density lipoproteins (VLDL), intermediate-density lipoproteins (IDL) and HDL. ApoE plays a major physiological role in lipoprotein metabolism, and it mediates the high-affinity binding of apoE-containing lipoproteins to the cell-surface LDL receptor and the chylomicron-remnant receptor; therefore, it is an important mediator of the transport and hepatic metabolic clearance of circulating cholesterol $[1,3,11,15]$. In C57 mice fed a chow diet, values of PC, triglycerides (TG), VLDL+IDL, LDL and HDL levels are approximately 60, $65,20,10$ and $50 \mathrm{mg} / \mathrm{dL}$, respectively $[3,11,16,17]$. In the homozygous apoE mutant mouse that is fed a chow diet, there is a shift in plasma lipoproteins from HDL to predominantly VLDL and chylomicron remnant fractions, i.e., most of the $\mathrm{PC}$ is in atherogenic lipoprotein fractions. Thus, on a chow diet, apoE ${ }^{-/-}$mice have increased total PC ( 8-fold), TG (1.7-fold), VLDL+IDL (18-fold) and LDL (14-fold), but similar or decreased HDL at all ages [3,11,16-21]. When fed a Western-type diet, a dramatic increase in the proportions of these lipids is observed in total PC ( 14-fold) and particularly in the VLDL+IDL lipoprotein fraction ( 30-fold) $[3,19,20,22-24]$. When fed a normal diet apoE ${ }^{-/-}$mice exhibit monocyte attachment to endothelial cells and a disruption of the subendothelial elastic lamina at 6-8 weeks of age, lesions containing foam cells and smooth muscle cells are seen at 8-10 weeks of age, and fibrous plaques appear at 15-20 weeks of age [3,25]. At 70 weeks-old, apoE $E^{-/-}$mice exhibit over $90 \%$ occlusion of the aortic lumen, and a similar percentage of occlusion is observed at 32 weeks when the animals are fed a Western-type diet [26]. Sites of predilection include the aortic root, aortic arch, common carotid, superior mesenteric, renal and pulmonary arteries [25,27]. Thus, similar to humans, apoE ${ }^{-/-}$mice display increased levels of total PC and extensive lipid deposition in the major large arteries, which is accelerated and aggravated when they are fed a Western-type diet, suggesting a similarity with humans.

\section{The influence of gender on atherosclerosis}

The influence of gender on atherosclerosis and the protective effect of estrogen are controversial. The majority of studies show that during their reproductive years, women are less prone to developing cardiovascular diseases and atherosclerosis than men, but men and post-menopausal women at comparable ages are at an equal risk for developing the disease as, as recently reviewed [28]. Consequently, cardiovascular diseases in women develop, on average, 10 years later than they do in men. In mice, large number of studies using apoE $\mathrm{E}^{-/-}$or LDL receptor-knockout mice have demonstrated an atheroprotective role for endogenous estrogen and estrogen replacement in females (reviewed 5 years ago [29]). However, after that time, emerged convincing evidence suggests that atherosclerotic lesions in apoE $\mathrm{E}^{-/-}$mice are greater in females than in males, and the reasons for this discrepancy are not clear. Therefore, the influence of gender on atherosclerosis in the apo: $\mathrm{E}^{-/-}$mouse is still under debate. For example, Tangirala et al. [30] showed that in LDL receptor-deficient mice, the incidence of atherosclerotic lesions in the aorta was significantly higher in males than in females. However, in apo: $\mathrm{E}^{-/-}$mice (mixed C57 $\times 129$ ola genetic background) fed a Western-type diet for 6 months (starting at 5-6 months old), they observed only a trend towards increased lesions in males compared to females (not significant). Similarly, Coleman et al. [26] did not encounter clear-cut gender differences in the histopathology of aortic arch atherosclerosis in 6- to 80-week-old apoE ${ }^{-/-}$mice (C57 genetic background) fed a standard chow diet. In addition, Elhage et al. [31] showed that although the total PC was higher in males than in females in apoE $\mathrm{E}^{-/-}$mice $(\mathrm{C} 57 \times$ 129/B6 genetic background) fed a chow diet, there was no statistical significance in the fatty streak areas between genders. In contrast, a recent study by Chiba et al. [32] showed that in apoE ${ }^{-/-}$mice (C57 genetic background) fed an atherogenic diet for 16 weeks, starting at 10 weeks of age, there were significant less atherosclerotic lesions in females than in males and greater in ovariectomized than in sham animals, without differences in serum lipoproteins between genders. The protective influence of female hormones against atherosclerosis in the apoE $\mathrm{E}^{-/-}$mouse is corroborated by the findings that estrogen administered to apoE $^{-/-}$mice $(\mathrm{C} 57 \times 129$ ola genetic background $)$ prevented fatty streak formation in female and male mice fed a chow diet [31] and reduced atherosclerotic lesion development 
in mice fed a Western-type diet [33]. In contrast, there is a growing body of convincing evidence against the atheroprotective effects of estrogen. For example, tamoxifen, which exhibits tissue-specific estrogen receptor agonist/ antagonist activities and has been shown to act as a cardioprotective agent in postmenopausal women [34], decreased cholesterol levels by 7 -fold and abolished lipid lesion development in apoE $\mathrm{E}^{-/-}$mice that received this therapy repeatedly [35]. In agreement with these observations, Caligiuri et al. [36] observed that in apoE ${ }^{-/-}$mice (C57 genetic background) fed a normal chow diet, young female mice developed larger and more advanced atherosclerotic lesions compared with young male mice. The data from this latter study suggest that differences in atherosclerotic lesions between genders may be related to differences in the cellular immune responses to the atheroscleroticrelated autoantigen, oxidized LDL (oxLDL), in the different sexes [36]. The presence of apoA in the HDL may also be a sex-related determinant for receptor interactions and this may be of pathophysiological importance in atherosclerosis. Indeed, compared to male apoE ${ }^{-/-}$mice, female apoE $\mathrm{E}^{-/-}$mice have lower plasma levels of apoA-I and apoA-II [21]. Moreover, it has been reported that in female mice, HDL and apoA-I are negatively associated with aortic atherosclerotic lesions, while the association with apoA-II was positive. In contrast, in males no significant associations were observed [21], indicating that changes in HDL and apoA are important determinants of atherosclerosis in females but not in males. Accordingly, in $a p o E^{-/-}$mice, fed a standard chow diet $[21,36]$ or a Western-type diet [5,24], females exhibit areas of larger vascular atherosclerotic lesions than males (see Figure 1). In a study it was also demonstrated that the elevated production of thromboxane $\left(\mathrm{TXA}_{2}\right)$ and the reduced production of prostacyclin $\left(\mathrm{PGI}_{2}\right)$ observed in female apoE $\mathrm{E}^{-/-}$mice (Figure 2) are gender-related proatherogenic risk factors in these animals [24]. Caligiuri et al. [36] showed that vascular atherosclerotic lesions were larger and more advanced in young (16-week-old) female apoE $\mathrm{E}^{-/-}$mice compared to male apoE ${ }^{-1-}$ mice, but in aged (48-week-old) animals, when the blood levels of estrogen decreased in females, there was no longer a sex difference in lesion size [36]. These data suggest that age- and sex-dependent variations of cell-mediated immune responses modulate the onset and progression of atherosclerosis. In support of these findings, a recent study showed that in apo: $\mathrm{E}^{-/-}$mice, atherosclerosis was reduced following ovariectomy and was aggravated following treatment with $17-\beta$-estradiol at doses that were similar to physiological levels of the hormone [37]. In view of these findings, the apoE $E^{-/-}$mouse model allows the investigation of the detrimental effects of $17-\beta$-estradiol on atherosclerosis and contributes to clinical studies that reveal the unfavorable effects of hormone replacement therapy in postmenopausal women. Although

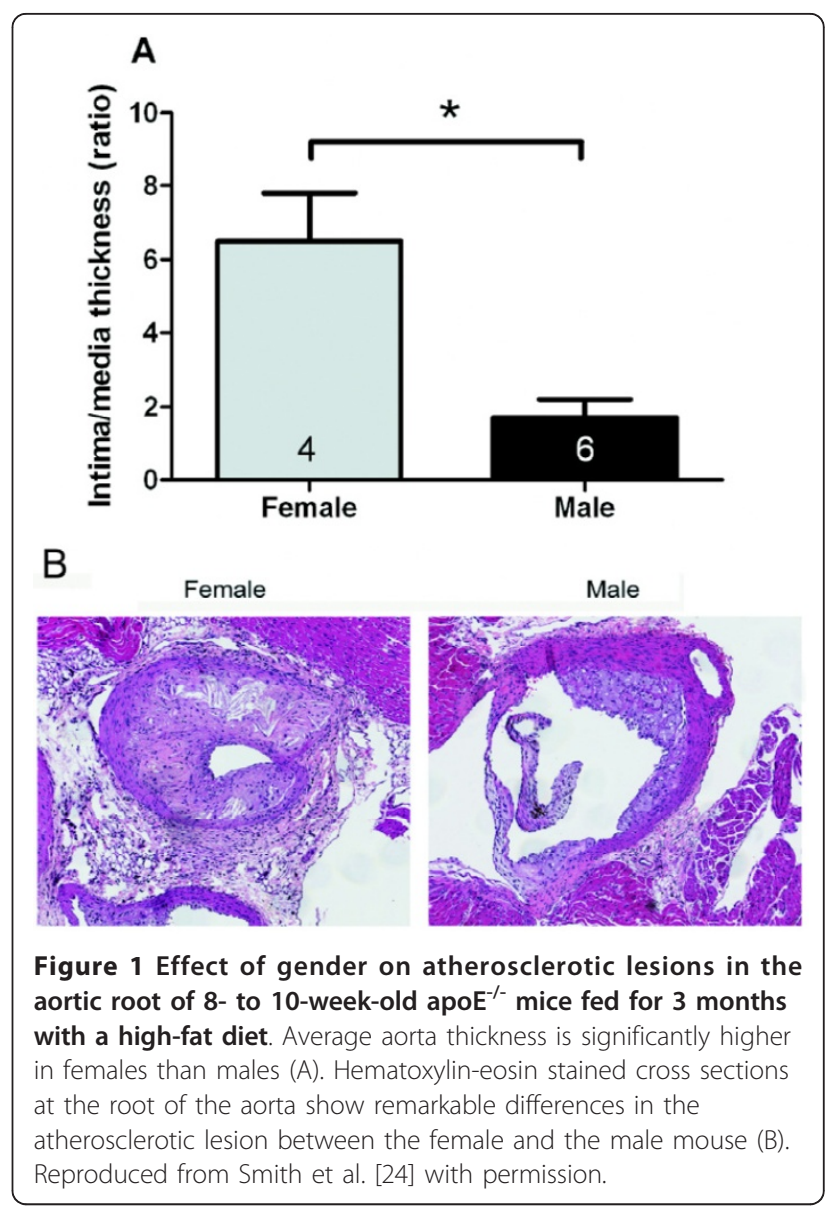

the influence of female gender on atherosclerosis is still controversial and more research is needed to understand fully the role played by estrogens in atherosclerotic lesion in the apoE $\mathrm{E}^{-/-}$mouse, there is convincing evidence that at a young age and on a normal chow diet, females develop greater atherosclerotic lesions than males. Indeed, the above study reporting greater atherosclerotic lesions in males than in females, the animals were 26-week-old and fed an atherogenic diet [32], whereas in the study reporting the opposite observation, the animals were younger and fed a regular chow diet and significant differences between the genders in the older animals were not observed [36]. In agreement with these observations, Maeda et al. [38] showed that atherosclerotic lesions at the aortic roots of apoE ${ }^{-/-}$mice (C57 genetic background) fed a regular chow diet developed plaques earlier in the females than in the males. Taken together, the above studies highlight the importance of considering sex in the analysis of atherosclerosis and lipid metabolism in the apoE $\mathrm{E}^{-/-}$mouse model, and they fuel the debate on the effects of estrogen on atherosclerosis in murine models.

Therefore, the deletion of the single apoE gene, which results in severe hypercholesterolemia, is sufficient to 


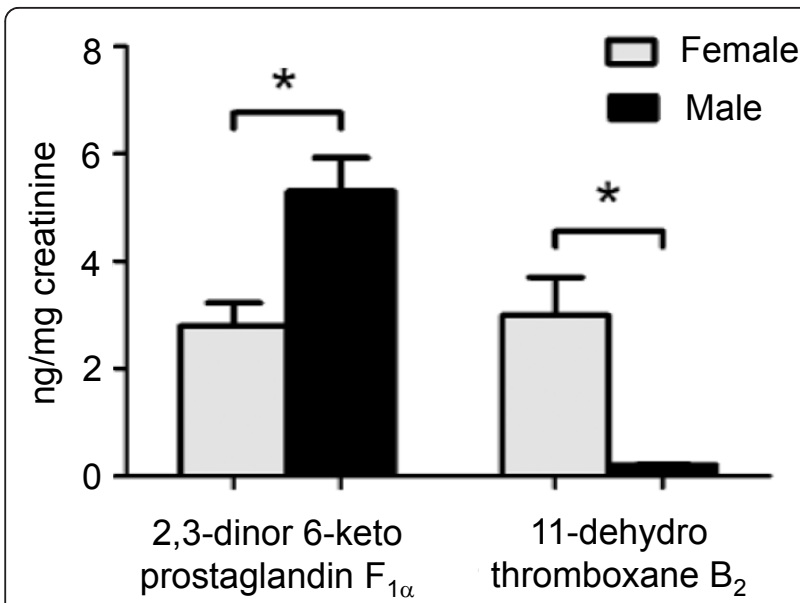

Figure 2 Effect of gender on the levels of 2,3-dinor-6-keto prostaglandin $F_{1 \alpha}$ and 11-dehydro thromboxane $B_{2}$ in 24-hour urine samples of $\mathrm{ApoE}^{-/-}$female and male mice after a 3-month high fat diet regimen. The data presented are as mean \pm SEM. * $p$ $<0.05$, when compared to males. Reproduced from Smith et al. [24] with permission.

convert the mouse from a species that is highly resistant to atherosclerosis to one that is highly susceptible to the disease $[2,3,11]$. The characterization of the morphology, histology, pathology and mechanisms (but not gender) involved in the development of vascular atherosclerotic lesions in this murine model of atherosclerosis has been broadly studied for two decades and has been previously reviewed $[1,9,10]$. However, the vascular endothelial dysfunction in the apoE ${ }^{-/-}$mouse has not been fully elucidated, and the main purpose of this brief review is to summarize and discuss the mechanisms underlying this vascular defect and to address the influence of diet, aging and gender.

\section{Endothelial Function in Physiological Conditions}

\section{Assessment of endothelial function and the role of nitric} oxide (NO)

The general aspects of endothelial function and atherosclerosis have been reviewed previously [39-41], and are summarized here. The vascular endothelium regulates vascular tone and structure in conductance and resistance vessels through a continuous release of a variety of autocrine and paracrine vasoactive mediators such as nitric oxide (NO), reactive oxygen species (ROS), endothelin-1 (ET-1), angiotensin (Ang) II, endotheliumderived hyperpolarizing factor (EDHF), prostacyclin $\left(\mathrm{PGI}_{2}\right)$ and epoxyeicosatrienoic acids (EET). Importantly, the position of the endothelium in the vessel wall makes it a primary target for injuries. As shown in the schematic representation in Figure 3, shear stress and acetylcholine (ACh), which is commonly used to asses endothelial function, and receptor-specific agonists, such as bradykinin, thrombin and serotonin, causes increase in intracellular $\mathrm{Ca}^{++}$levels. This increase in $\mathrm{Ca}^{++}$activates endothelial NO synthase (eNOS), which acts on Larginine (L-arg) resulting in the production of NO. This reaction requires the participation of cofactors, such as tetrahydrobiopterin $\left(\mathrm{BH}_{4}\right)$ and $\mathrm{NADPH}$, which are critical for coupling the reduction of molecular oxygen $\left(\mathrm{O}_{2}\right)$ and the oxidation of L-arg, resulting in the production of NO and L-citrulline [42-45]. NO diffuses to the underlying vascular smooth muscle cells (VSMC), where it activates soluble guanylyl cyclase (sGC) to produce cyclic guanosine monophosphate (cGMP) from guanosine triphosphate (GTP), and induces a decrease in $\mathrm{Ca}^{++}$ followed by VSMC relaxation.

\section{Endothelial generation of reactive oxygen species (ROS)} and other vasoactive mediators

As illustrated in Figure 3, this reaction of the endothelial cell involving the L-arg-eNOS system also generates ROS, including the free radicals (unpaired electrons) superoxide anions $\left(\cdot \mathrm{O}_{2}{ }^{-}\right)$, peroxynitrite $\left(\cdot \mathrm{ONOO}^{-}\right)$, and hydroxyl radicals $\left(\mathrm{OH}^{\cdot} \mathrm{O}\right)$ and non-radicals, such as hydrogen peroxide $\left(\mathrm{H}_{2} \mathrm{O}_{2}\right)$, that are involved in diverse cardiovascular diseases [46-50]. Briefly, $\bullet \mathrm{O}_{2}^{-}$reacts extremely rapid with $\mathrm{NO}$ generating ONOO$^{-}$. Superoxide anions are also rapidly scavenged by the antioxidant enzyme SOD, thus protecting $\mathrm{NO}$ and generating $\mathrm{H}_{2} \mathrm{O}_{2}$. Under physiological conditions, this interaction is minimized by endogenous antioxidant defenses, such as SOD, and the low levels of ROS act as signals to modulate proliferation, apoptosis and gene expression through the activation of transcription factors. ROSs are produced by all vascular cell types, and have been implicated in the regulation of vascular tone by modulating vasodilation directly or indirectly by decreasing $\mathrm{NO}$ bioavailability through quenching by $\cdot \mathrm{O}_{2}{ }^{-}$to form - $\mathrm{ONOO}^{-}$, which is a short-lived species that impairs endothelial function. In contrast, high concentrations and/or the inadequate removal of $\mathrm{ROS}$, especially $\cdot \mathrm{O}_{2}{ }^{-}$, results in oxidative stress, which has been implicated in the pathogenesis of many cardiovascular diseases including hypercholesterolemia and atherosclerosis.

Endothelium releases other potent vasodilator substances, such as $\mathrm{PGI}_{2}$, an eicosanoid of the cyclooxygenases pathway. The activities of $\mathrm{PGI}_{2}$ include the activation of adenylate cyclase (AC) in VSMCs, which results in the generation of 3'-5'-cyclic adenosine monophosphate (cAMP), causing a relaxation of the VSMC in most blood vessels. An additional relaxant pathway acts through the release of EDHF that diffuses to and activates VSMC potassium channels, causing hyperpolarization [47]. Reliable data [47-49], indicate that $\mathrm{H}_{2} \mathrm{O}_{2}$ derived from the dismutation of $\mathrm{O}_{2}{ }^{-}$may act as an EDHF because it elicits hyperpolarization and 


\section{Endothelial Function in Physiological Conditions (coupled eNOS)}



Figure 3 Hypothetical scheme illustrating the possible biochemical pathways for the production of nitric oxide (NO) and reactive oxygen species (ROS) by endothelial cells under physiological conditions, including specific pharmacological tools that are used to study the vascular function (blue lines). The predominant pathways that lead to normal endothelial vasodilation are indicated by thick lines/ arrows. Abbreviations: AA, arachidonic acid; AC, adenylate cyclase; $\mathrm{BH}_{4}$, tetrahydrobiopterin; CAMP, 3'-5'-cyclic adenosine monophosphate; $\mathrm{CGMP}$, cyclic guanosine monophosphate; Cox, cyclooxygenases; EDHF, endothelium-derived hyperpolarizing factor; EET, epoxyeicosatrienoic acids; eNOS, endothelial nitric oxide synthase; $\mathrm{H}_{2} \mathrm{O}_{2}$, hydrogen peroxide; L-arg, L-arginine; L-NAME, L-nitroarginine methylester; Lox, lipoxygenases; NADPH, nicotinamide adenine dinucleotide phosphate; $\cdot \mathrm{O}_{2}{ }^{-}$, superoxide anion; $\cdot \mathrm{ONOO}$, peroxynitrite; $\mathrm{PDE}$, phosphodiesterase type 5 ; $\mathrm{PG} \mathrm{I}_{2}$, prostacyclin; SGC, soluble guanylyl cyclase; SOD, superoxide dismutase; SNP, sodium nitroprusside.

vasodilation by activating VSMC potassium channels. In large vessels, $\mathrm{H}_{2} \mathrm{O}_{2}$-induced relaxation can be endothelium-independent and endothelium-dependent, as indicated by the observation that the eNOS inhibitor L- nitroarginine methylester (L-NAME) abolishes this effect $[51,52]$. The vasodilator activity of $\mathrm{H}_{2} \mathrm{O}_{2}$ also affects mesenteric and coronary arteries, and in coronary arteries, it has been shown to involve COX-1 and the 
VSMC potassium channel $[53,54]$. Therefore, there are substantial data indicating that the four main mediators of endothelial vasodilator function, $\mathrm{NO}, \mathrm{H}_{2} \mathrm{O}_{2}, \mathrm{PGI}_{2}$ and EDHF, interact in a coordinated manner to maintain normal endothelial function $[55,56]$. In terms of relative importance, studies $[51,52,54]$ show that NO is the predominant endothelium-derived vasodilator in large arteries, whereas in resistance vessels of the microcirculation EDHF predominates over other agents. The impairment of vascular function, which is associated with several cardiovascular events and atherosclerosis, has typically been characterized by one or more of the following responses: decreased endothelium-dependent vascular relaxations, decreased endothelium-independent vascular relaxations, and/or increased vasoconstrictions [57-60].

\section{Endothelial Function and Dysfunction in the ApoE ${ }^{-/-}$Mouse}

The influence of diet, age and gender on endothelial function of large arteries

One hallmark of atherosclerosis is vascular dysfunction, which is observed mainly in large vessels and has generally been defined by a decreased in endothelium-dependent vasodilation that is generally considered to precede the development of atherosclerosis and to predispose humans to the development of structural vascular changes [61]. However, this general concept is not fully supported by studies in the murine model of spontaneous hypercholesterolemia and atherosclerosis. Indeed, aortic rings isolated from young (6-18-week-old) male and female apoE $\mathrm{E}^{-/-}$mice fed a standard chow diet (hypercholesterolemia only) exhibit a preserved endothelial NOdependent relaxation response to $\mathrm{ACh}$ when compared with wild-type control mice $[12,62,63]$. Similar results have been observed in aortas from adult (20-35-weekold) male [64] and female $[4,65] \mathrm{apoE}^{-/-}$mice. In contrast, in aged apoE ${ }^{-/-}$mice (50-70-week-old) that exhibit both hypercholesterolemia and established atherosclerosis, an endothelial dysfunction, as demonstrated by a significantly blunted aorta relaxation response to $\mathrm{ACh}$, has been observed $[62,66,67]$. When apoE ${ }^{-/-}$mice are fed a Western-type diet to accelerate and aggravate hypercholesterolemia and atherosclerosis, the vasodilation response to $\mathrm{ACh}$ in the aortas $[23,64,65]$ and carotid arteries [23] of 20-30-week-old males is normal; however, studies have shown a significant impairment of the vasodilation response to ACh in 14-15-week-old male $[22,65,68-76]$ and female $[4,19,77]$ mice. Crauwels et al. [66] demonstrated that in aged (72-week-old) apoE $E^{-/-}$ mice, the aortic endothelial dysfunction is a focal and not a systemic hypercholesterolemia-dependent defect, i.e., it is strictly associated with plaque formation. Overall, the above findings (see diagram in Figure 4) suggest that endothelial function in the aortas of $\operatorname{apoE}^{-1-}$ mice is normal at the early stages of the pathology and the impairment of endothelial NO-mediated dilation occurs at a later stage, mainly in aged animals and when mice are fed an atherogenic Western-type diet, which aggravates hypercholesterolemia and atherosclerosis.

Recent evidence suggests that gender plays an important role in endothelial dysfunction in the large vessels of apoE $E^{-1-}$ mice. Indeed, atherosclerosis in $\mathrm{apoE}^{-/-}$mice was reduced and the endothelial dysfunction of aortic rings was attenuated following ovariectomy and was aggravated by treatment with 17- $\beta$-estradiol at doses that were near physiological levels [37]. Hence, the $\mathrm{apoE}^{-1-}$ mouse, in addition to being a model for human atherosclerosis, appears to be a suitable experimental model for studying the detrimental effects of $17-\beta$-estradiol on endothelial dysfunction [37]. Despite a growing body of evidence suggesting that gender influences atherosclerosis in apoE ${ }^{-/-}$mice [30-38], few studies have investigated the differences in endothelial function between males and females. More interesting is that a large number of publications have not revealed the gender of the mice used in the studies.

In humans, there is a general concept that endothelial dysfunction precedes the development of atherosclerosis [41]. Moreover, there is evidence that the impaired endothelial NO-dependent relaxation response to ACh in apo $^{-/-}$mice is not determined by hypercholesterolemia alone. The hypothesis that endothelial dysfunction in large vessels of apoE $\mathrm{E}^{-/-}$mice is dependent on plaque formation was tested by Bonthu et al. [12] using a different experimental design. They examined the endothelium-dependent relaxation of aortic rings from 19-weekold apoE $E^{-/-}$mice and apoE $E^{-/-} / \mathrm{LDL}$ receptor-deficient (double knockout) mice fed a standard chow diet and compared them with wild-type C57mice. Relaxation in response to $\mathrm{ACh}$ of the proximal and distal segments of thoracic aortas from apoE $\mathrm{E}^{-/-}$mice (atherosclerotic lesions were minimal or absent) was normal; however, the relaxation response was greatly impaired in the proximal segments of thoracic aortas (containing atherosclerotic lesions) from the double knockout mice but not in distal segments that had minimal or no atherosclerotic lesions. Similarly, others have observed a decrease in NO-dependent vasodilation in atherosclerosis-prone regions, whereas it was preserved in regions that are less prone to atherosclerosis in the descending thoracic aorta of female apo: $\mathrm{E}^{-/-}$mice fed a high-cholesterol diet [77]. These findings indicate that aortic endothelial dysfunction in mice is a focal (plaquerelated) and not a systemic hypercholesterolemia-dependent defect [66]. Supporting this observation, is the report that human apoAI transgenesis, which is known to raise $\mathrm{HDL}$, attenuates atherogenesis and improves aortic vasomotor responses to $\mathrm{ACh}$ in apoE $\mathrm{E}^{-/-}$mice [4] 




in vessel segments that exhibit large lesions but not those with smaller lesions [66]. This observation explains the association of high plasma HDL levels with the normal endothelium-dependent vasorelaxation that is observed in humans [78]. However, this conclusion may have limitations when considering conductance arteries other than the aorta. For example, young ( 15 weeks old) [79] or adult ( 30 weeks old) [80] $\mathrm{apoE}^{-/-}$ mice demonstrate impaired endothelial-dependent relaxation in the common carotid arteries despite the fact that no morphological changes were observed in these vessels at that age (illustrated in Figure 5). These observations suggest that in contrast to the aorta, endothelial dysfunction can occur in other non-atherosclerotic arteries and that the apoE $\mathrm{E}^{-/-}$mouse carotid artery is a valuable experimental model for endothelial dysfunction in conditions of hypercholesterolemia alone.

\section{The role of endothelial NO bioavailability and endothelin} in endothelial dysfunction of large arteries

The endothelial dysfunction of large vessels in hypercholesterolemia and other cardiovascular diseases has been attributed to the following: (a) a decrease in NO production or eNOS synthesis/activity; (b) excessive production of vascular $\mathrm{ROS}$, where $\cdot \mathrm{O}_{2}{ }^{-}$reacts with $\mathrm{NO}$, resulting in the formation of ${ }^{\cdot \mathrm{ONOO}^{-}}$and a decreased in the bioavailability of NO; (c) the local oxidation of circulating lipoproteins and/or (d) a decreased antioxidant capacity (see scheme in Figure 6). There is evidence that the chemical inactivation and reduced biosynthesis of NO are the key mechanisms responsible for endothelial dysfunction in the aortas of atherosclerotic apoE $E^{-/-}$mice $[12,69]$. Vascular relaxation responses to $\mathrm{ACh}$ are attenuated by the inhibition of NOS by L-NNA in aortas from normal mice and in segments of aortas that have no intimal thickening in $\mathrm{apoE}^{-/-}$mice [12]. Similarly, aortas from young apo: $\mathrm{E}^{-/-}$mice fed a regular chow diet exhibit normal eNOS expression and normal dilation responses to ACh $[63,64]$. However, transfer of the eNOS gene into apo- ${ }^{-/-}$mice carotid arteries in vivo results in increased eNOS expression levels and normalized relaxation responses to $\mathrm{ACh}$ [72]. Interestingly, apo: ${ }^{-/-}$mice fed a Western-type diet exhibit increased vascular ET-1 production, reduced endothelial NO 


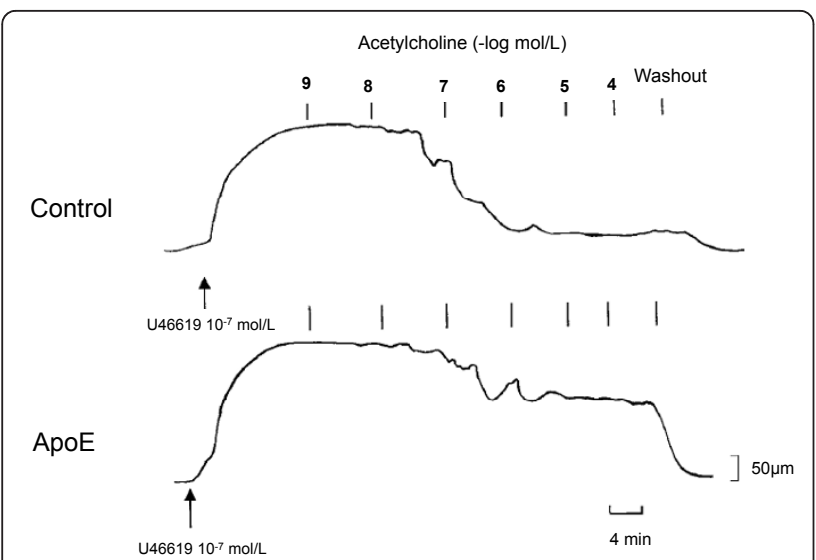

Figure $5 \mathrm{~A}$ tracing illustrating the reduced acetylcholineinduced vasorelaxation of a common carotid artery ring that was precontracted using the thromboxane analog U46619 in a male apolipoprotein E-deficient (ApoE) mouse compared with a wild-type C57BL/6J (control) mouse. Both animals were fed a lipid-rich Western-type diet for 26 weeks. Reproduced with permission from d'Uscio et al. [80].

release, and impaired endothelium-dependent relaxation, which are all normalized by chronic blockage of the $\mathrm{ET}_{\mathrm{A}}$ receptor [68]. These data suggest that a key mechanism underlying the endothelial dysfunction in atherosclerotic large vessels in apoE $\mathrm{E}^{-/-}$mice is a decreasing bioavailability of $\mathrm{NO}$, which appears to be associated with the activation of the ET-1 system. From a clinical viewpoint, the current data demonstrate that the blockage of the $\mathrm{ET}_{\mathrm{A}}$ receptor may have therapeutic potential in patients suffering from endothelial dysfunction [81].

\section{The role of reactive oxygen species (ROS) and angiotensin in endothelial dysfunction of large arteries}

Reduced endothelial NO bioavailability has also been attributed to a deficiency in substrates or cofactors or to the enhanced formation of $\cdot \mathrm{O}_{2}{ }^{-}$, which reacts with $\mathrm{NO}$ in apoE $E^{-/-}$mice $[7,69]$ and in other experimental and clinical studies of cardiovascular pathophysiologies $[58,59]$. In hypercholesterolemia, when lipids can be incorporated into the endothelium, eNOS becomes uncoupled leading to the generation of ROS (including ${ }^{-\mathrm{O}_{2}}{ }^{-}, \mathrm{H}_{2} \mathrm{O}_{2}, \mathrm{OH}^{\cdot} \mathrm{O}$, and the strong oxidant $\cdot \mathrm{ONOO}^{-}$) instead of $\mathrm{NO}$. Taking into consideration that $\mathrm{BH}_{4}$ is highly susceptible to oxidative degradation by $\bullet \mathrm{O}_{2}{ }^{-}$or $\bullet \mathrm{ONOO}^{-}$, the initial degradation of $\mathrm{BH}_{4}$ by $\mathrm{ROS}$ derived from another source induces eNOS uncoupling and the amplification of oxidative stress in conditions of hypercholesterolemia and atherosclerosis in human [82] and in apoE ${ }^{-/-}$mice [83]. Indeed, endothelial dysfunction is abolished by $\mathrm{BH}_{4}$ supplementation in hypercholesterolemic patients [82]. Thus, depletion of $\mathrm{BH}_{4}$ (e.g., oxidized by $\cdot \mathrm{ONOO}^{-}$) may have an impact on turning eNOS into an $\cdot \mathrm{O}_{2}{ }^{-}$generating enzyme and thereby may lead to endothelial dysfunction. In apo: $E^{-1-}$ mice endothelial dysfunction is associated with increased $\bullet \mathrm{O}_{2}$ and decreased eNOS activity $[7,69]$. NADPH oxidase, which transfers electrons from NADH or NADPH to molecular oxygen to produce $\cdot \mathrm{O}_{2}{ }^{-}$, is necessary for the normal progression of atherogenic lesions in apo: $\mathrm{E}^{-/-}$mice $[84,85]$. In the conducting vessels of hypercholesterolemic mice, it has been reported that NADPH oxidase contributes markedly to the impairment of endothelium-dependent vasodilatation by inactivating $\mathrm{NO}$ and increasing oxidative stress $[85,86]$. Accordingly, the inhibition of NADPH oxidase by apocynin improves $\mathrm{ACh}$-induced relaxation in the superior mesenteric artery [86]. Similarly, an SOD mimetic was shown to reverse aortic endothelial dysfunction in $\mathrm{apoE}^{-1-}$ mice by decreasing the levels of $\mathrm{NADPH}$ oxidase-dependent $\cdot \mathrm{O}_{2}{ }^{-}$[87]. In support of these findings, it was shown that antianginal and anti-ischemic ivabradine reduced vascular NADPH oxidase activity, improved aorta endothelial function and reduced atherosclerotic plaque in young apo: ${ }^{-/-}$mice fed a Western-type diet [74]. Moreover, apoE ${ }^{-1-}$ mice that are genetically deficient in NADPH oxidase show retarded development of atherosclerosis in the aorta [84]. Angiotensin also plays an important role in this process, as demonstrated by Daugherty et al. [88] in LDL receptor-deficient and Ang $\mathrm{AT}_{1 \mathrm{~A}}$ receptor-deficient mice. In addition to the augmented systemic renin-angiotensin system, locally formed Ang II appears to play an important role in the mechanism that affects NO bioavailability, as indicated by the discovery that hypercholesterolemia may trigger the upregulation of vascular chymase, which may be involved in intimal lipid deposition, and may facilitate the development of atherosclerosis [89]. In apoE ${ }^{-1-}$ mice, Ang II also contributes to increased NADPH-dependent vascular $\bullet \mathrm{O}_{2}{ }^{-}$production and is implicated in the pathogenesis of atherosclerosis and endothelial dysfunction in this model [7,90-93]. This concept is supported by the finding that the inhibition of Ang II normalizes vascular $\bullet \mathrm{O}_{2}^{-}$and NADPH oxidase activity and improves endothelial dysfunction in young atherosclerotic animals [94]. This observation suggests a crucial role for Ang II-mediated $\cdot \mathrm{O}_{2}{ }^{-}$production in the early stages of atherosclerosis. Contrarily, some fragments of the renin angiotensin system can counteract the deleterious actions of ROS, as indicated by the finding that the treatment of apoE $E^{-1-}$ mice with Ang IV [75] or Ang 1-7 [76] improved aortic endothelial function, which was associated with decreased $\bullet \mathrm{O}_{2}{ }^{-}$levels and increased eNOS expression, i.e. increased NO bioavailability $[75,76]$. Therefore, the uncoupling of eNOS in the endothelium may lead to oxidative stress and endothelial dysfunction via (a) the diminished enzymatic production of NO, (b) the increased production of $\cdot \mathrm{O}_{2}{ }^{-}$contributing to oxidative stress, and (c) the simultaneous production of $\mathrm{NO}$ and $\cdot \mathrm{O}_{2}{ }^{-}$, generating - ONOO'. 


\section{Endothelial Dysfunction in Hypercholesterolemia (uncoupled eNOS)}

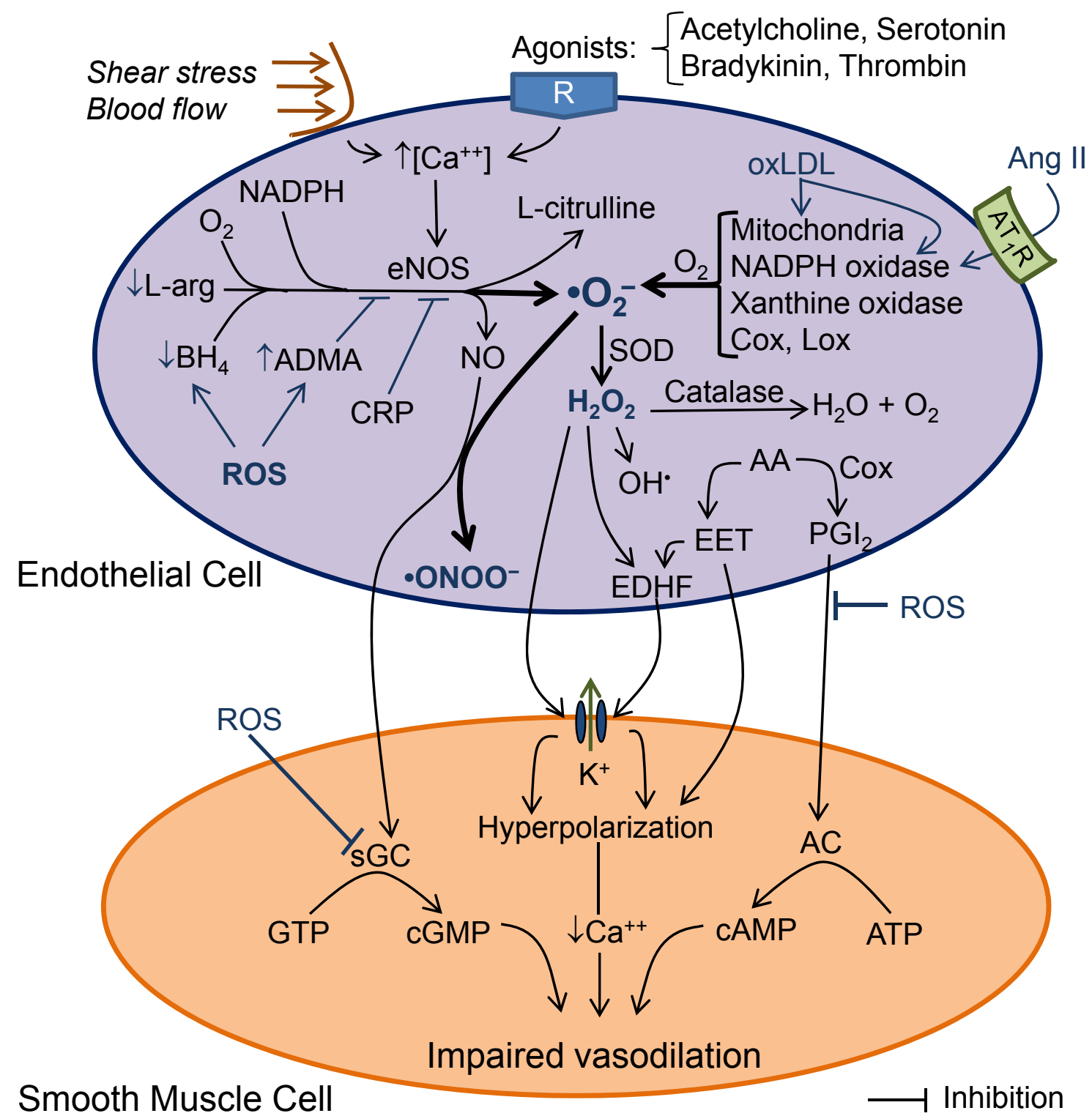

Figure 6 Hypothetical scheme illustrating the possible mechanisms that lead to endothelial nitric oxide synthase (eNOS) uncoupling (thick lines/arrows), which results in a reduction of nitric oxide (NO) release and an exacerbation of superoxide anion $\left(\cdot \mathrm{O}_{2}{ }^{-}\right)$ production, generating peroxynitrite $\left(\cdot \mathrm{ONOO}^{-}\right)$and thus, leading to impaired vasodilation. The main causes of the generation of excessive $\cdot \mathrm{O}_{2}{ }^{-}$and the resultant endothelial dysfunction are highlighted. Abbreviations (some are listed in Figure 3): ADMA, asymmetric dimethyl-Larginine; Ang II, angiotensin II; AT R, Ang II type 1 receptor; CRP, C-reactive protein; Lox, lipoxygenases; oxLDL, oxidized low-density lipoprotein.

The role of endothelial antioxidant enzymes and smooth muscle cell cGMP and cAMP

Impairment of endothelial dysfunction in large vessels may also be related to the abnormal degradation and/or inactivation of $\mathrm{NO}$ by $\cdot \mathrm{O}_{2}{ }^{-}$because of the incorporation of lipids within the endothelium [12]. Thus, the functional integrity of antioxidant enzymes e.g., SOD, glutathione peroxidase, heme and oxygenase, is important for protection against oxidative stress and endothelial dysfunction. Accordingly, aortas from apoE ${ }^{-/-}$mice fed a Western-type diet showed an impaired dilation response to $\mathrm{ACh}$ and a decreased SOD activity compared to apoE ${ }^{-/-}$mice fed a normal chow 
diet [65]. Although reports show that SOD protein expression is unaltered in aorta that are exposed to hypercholesterolemia [69], SOD mimetics reduced $\bullet \mathrm{O}_{2}$ - production and partially normalized relaxation in response to $\mathrm{ACh}$ in aortic and carotid arteries from apoE $E^{-1-}$ mice $[69,80,87]$. Moreover, increased $\bullet \mathrm{O}_{2}^{-}$levels and impaired relaxation in response to $\mathrm{ACh}$ were observed in the carotid arteries of aged ( $\sim 65$-week-old) apoE ${ }^{-/-}$mice that are heterozygous for the mitochondrial isoform of SOD2 $\left(\mathrm{apoE}^{-/-} / \mathrm{SOD} 2^{+-}\right)$ compared with mice that are homozygous for the gene $\left(\right.$ apoE $\left.^{-/ /} / \mathrm{SOD}^{+/+}\right)$, although PC levels and intimal areas were similar [8]. Thus, during the last three decades, accumulating evidence suggests that the main mechanism involved in endothelial dysfunction in hypercholesterolemic mice is the decrease in the bioavailability of endothelial NO due to a reduction in eNOS activity and/or a breakdown of NO by $\cdot \mathrm{O}_{2}^{-}$. Because of these new insights into the mechanisms of endothelial dysfunction, it is anticipated that specific therapies will be developed to prevent and treat the endothelial dysfunction that is observed in hypercholesterolemia and atherosclerosis.

Some studies have examined the hypothesis that the vascular dysfunction may be dependent not only on the reduced bioavailability of $\mathrm{NO}$ but also on the altered responsiveness of VSMCs to NO. Therefore, the functional integrity of the VSMC has been tested to determine the contribution of this vascular layer to the vascular dysfunction. Interestingly, cGMP levels were significantly reduced in the atherosclerotic aortas [69] but not in the carotid arteries without morphological changes [80] from male apoE ${ }^{-1-}$ mice fed a Western-type diet, indicating that a selective loss of cGMP-dependent vascular function is associated with atherosclerosis in this animal model. Others have shown that in apoE $E^{-1-}$ mice exhibiting normal $[4,12,16]$ or impaired $[4,6,7,62,71$, $73,80,85]$ endothelial $\mathrm{NO}$-dependent relaxations, the endothelium-independent vasorelaxation in response to an NO donor, i.e., sodium nitroprusside (SNP), was not affected, indicating that the responsiveness of the VSMC to NO is preserved. However, an attenuated endothelium-independent response was observed in atherosclerotic aortas from apoE ${ }^{-/-}$mice fed a lipid-rich Western-type diet [69] but it was not observed in non-atherosclerotic carotid arteries [80]. Thus, despite some controversies, there is evidence that the apoE $\mathrm{E}^{-1-}$ mouse, in addition to its endothelial dysfunction, exhibits decreased VSMC responsiveness to $\mathrm{NO}$ in conducting arteries that have atherosclerotic lesions but not in conducting arteries that do not have atherosclerotic lesions.

\section{Promising approaches for the treatment of vascular wall oxidative stress and endothelial dysfunction}

The incorporation of lipids within the endothelium, an early manifestation of atherosclerosis, and the associated oxidative processes may contribute to the degradation of NO [12]. The assumption that oxLDL plays a pivotal role in the pathogenesis of endothelial NO dysfunction is based on the findings of Jiang et al. [22], who demonstrated that the in vitro treatment of aorta with oxLDL mimicked the endothelial NO dysfunction that was observed in apoE $E^{-1-}$ mice. Moreover, adenovirusmediated gene transfer of the human paraoxonase 1 (PON1), an HDL-associated enzyme that destroys lipid peroxides, into aged apoE ${ }^{-/-}$mice with advanced atherosclerosis, decreased the oxLDL content of the plaques and restored endothelial function in plaque-bearing but not in plaque-free segments of the thoracic aorta [67]. In addition, macro and microvascular function in $\mathrm{apoE}^{-/-}$mice was restored by treatment with large empty phospholipid vesicles, which accelerates the reverse pathway of lipid transport from peripheral tissues to the liver [95]. These data show that oxLDL plays an important role in the pathogenesis of endothelial NO dysfunction in apoE mice and points to additional promising approaches for the treatment of vascular wall oxidative stress and endothelial dysfunction in atherogenic hyperlipidemia. As reviewed elsewhere [39,60], several studies of the therapeutic effect of lipid-lowering statins on endothelial dysfunction have resulted in an improvement of the endothelium-dependent dilation of coronary and peripheral arteries in patients, independent of its PC-lowering effects. In hypercholesterolemic apoE ${ }^{-1-}$ mice, it has been shown that statin treatment promotes eNOS function in aortic extracts [96]. In apoE $E^{-1-}$ mice suffering from hypercholesterolemia and atherosclerosis, statin therapy prevents the deficit in the bioavailability of NO in carotid arteries [23]. Interestingly, statins prevent the enhanced vasoconstrictor response to ET-1 of aortas in apoE $\mathrm{E}^{-/-}$mice, independent of their lipid-lowering properties [97]. The potential of statins for the prevention and treatment of endothelial dysfunction in the apo $\mathrm{E}^{-/-}$mouse is currently under intense investigation. Other therapies have also been tested, including the systemic administration of rapamycin-eluting stents, which have been used for percutaneous coronary interventions and are associated with high eNOS and protection against atherosclerosis. Although rapamycin treatment can protect against atherosclerosis in carotid arteries [98], studies from our laboratory show that this agent does not affect vascular responsiveness in the resistance mesenteric arteries of apoE ${ }^{-/-}$mice [99]. The effect of non-pharmacological therapies on vascular dysfunction in hypercholesterolemic mice has also been tested. For example, physical exercise has been shown to prevent the progression of atherosclerotic lesions and the endothelial NO-dependent dysfunction of thoracic aortas from apoE $E^{-1-}$ mice $[73,85]$. This effect is likely a result of improving the sensitivity of vasorelaxations 
induced by vasodilating agents and shear stress and by improving the efficiency of signaling events that lead to an increase in NO bioactivity $[19,73]$. The above data also provide a rationale for further studies aimed at testing new preventive and corrective therapies for endothelial dysfunction in atherosclerotic disease. In this context, there is an urgent need for the development of sensitive and specific biomarkers to assess the oxidant status of patients with endothelial dysfunction.

\section{The endothelial dysfunction in resistance vessels}

Because the vascular morphology function of the microcirculation and large vessels differ, the conclusions based on data obtained from large arteries cannot be generalized and applied to microcirculation. However, in contrast to large arteries, much less is known about the effects of hypercholesterolemia on resistance vessels, which are of physiological importance in the control of blood flow and organ perfusion. Hypercholesterolemia also impairs the endothelium NO-dependent function in the resistance arteries of patients [100], despite the fact that the resistance vessels rarely exhibit atherosclerosis. Studies have shown that young (6-19-week-old) male apoE $^{-1-}$ mice fed a standard chow diet (hypercholesterolemia only) have a preserved endothelial NO-dependent relaxation response to $\mathrm{ACh}$ in cutaneous vessels [101] and in the mesenteric vascular bed [102,103]. A similar phenotype has been reported in the mesenteric arteries $[20,99]$ and skeletal muscle resistance arterioles $[16,104]$ in adult male (20-40-week-old) mice. Interestingly, the coronary resistance vessels from this murine model fed a regular chow diet do not exhibit impaired vasodilator responses to $\mathrm{ACh}$ (or to $\mathrm{PGE}_{2}$ mimetics), but they do exhibit impaired vasodilator response to bradykinin $[105,106]$. Nevertheless, when apoE ${ }^{-1-}$ mice are fed a Western-type diet, the ACh-induced relaxation responses in coronary arterioles and in segments of mesenteric arteries are attenuated and increased levels of ET-1 are observed [20,106,107]. As outlined for large vessels, gender can also be an important factor that influences endothelial dysfunction in resistance vessels. Indeed, as shown in Figure 7, an impaired relaxation response to $\mathrm{ACh}$ in resistance mesenteric arteries was reported in female [108], but not in male [102] $\mathrm{apoE}^{-/-}$ mice fed a standard chow diet. Reduced responses to ACh were also reported in cerebral arterioles from female apoE ${ }^{-1-}$ mice fed either normal or high-fat diets despite the absence of atherosclerotic lesions in those vessels [109]. In the same study, the authors also noted that although female apoE $\mathrm{E}^{-1-}$ mice on high-fat diet had higher total PC levels and more extensive atherosclerotic lesions in the aorta than either the control or apoE $\mathrm{E}^{-/-}$ mice on a normal diet, the impairment of the responses to ACh was similar in on both normal and high-fat diet apoE $^{-/-}$mice. Hypercholesterolemia, even without morphological changes in resistance vessels, is associated with endothelial dysfunction in females but is not consistently observed in males. Therefore, one must be cautious when interpreting these results because female apoE $E^{-/-}$mice may be more susceptible to developing endothelial dysfunction, as suggested by evidence showing that females are more prone to developing atherosclerosis than males $[5,21,24,36]$.

\section{The role of NO, ROS and endothelin in endothelial dysfunction of resistance vessels}

It has been proposed that in resistance vessels in mice, the predominant agonist-induced endothelium-dependent vasodilation is not mediated by $\mathrm{NO}, \mathrm{PGI}_{2}$ or $\mathrm{sGC}$ but by $\mathrm{H}_{2} \mathrm{O}_{2}$ or an EDHF-like principle agent $[54,110]$. Accordingly, in the cerebral arterioles of hypercholesterolemic female mice, endothelium-dependent dilator responses are improved by treatment with the cell permeable SOD mimetic tempol, a superoxide

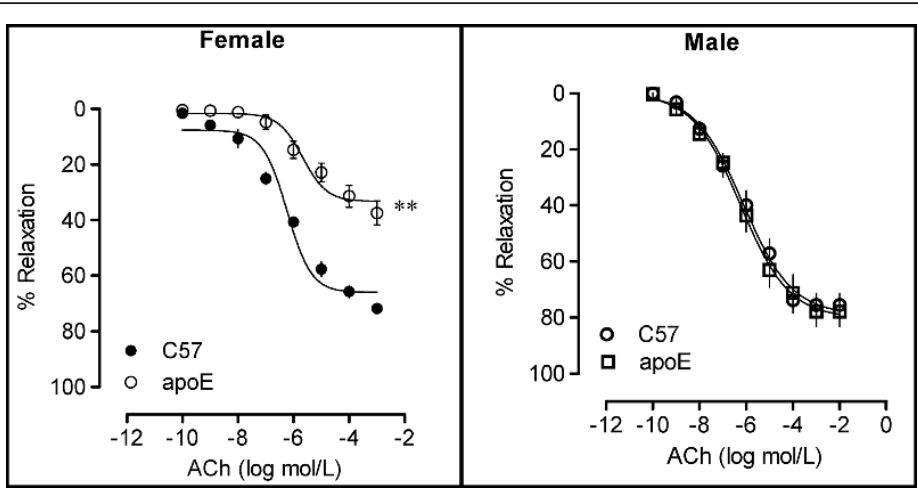

Figure 7 Graphs showing impaired endothelium-dependent relaxation in response to acetylcholine (ACh) in mesenteric resistance arteries of female but not male apoE ${ }^{-/}$mice fed a regular chow diet. The values are means $\pm \mathrm{SEM}$. ${ }^{* *} \mathrm{p}<0.01$ compared with wild-type (C57) mice. Reproduced with permission from Arruda et al. [102] (right panel) and from Cola et al. [108] (left panel). 
scavenger, and apocynin, an inhibitor of NADPH oxidase [109], suggesting that hypercholesterolemia may modulate cerebral arteriolar dysfunction, at least in part, via NADPH oxidase-derived $\bullet^{-} \mathrm{O}_{2}$. Likewise, coronary resistance vessels from apoE ${ }^{-/-}$mice demonstrate a preserved function of the $\mathrm{PGI}_{2}$ system; however, NADPH induced $\cdot \mathrm{O}_{2}{ }^{-}$formation was enhanced in cardiac extracts from hearts, and the vasodilator response to bradykinin was practically abolished by an SOD mimetic [105] indicating that the endothelial dysfunction in these vessels is likely mediated by the inactivation of bioavailable $\mathrm{NO}$ by $\cdot \mathrm{O}_{2}{ }^{-}$. Moreover, others have shown that in $\mathrm{apoE}^{-1-}$ mice fed a Western-type diet, the impairment of the vasodilator response of coronary arterioles to $\mathrm{ACh}$ was partially restored by the NADPH oxidase inhibitor apocynin [107]. These findings indicate that the endothelial dysfunction in coronary resistance vessels is not due to a reduced eNOS expression, but is most likely a result of the inactivation of bioavailable $\mathrm{NO}$ by - $\mathrm{O}_{2}$. However, in mesenteric arteries from male apoE $\mathrm{E}^{-/-}$ mice, the impaired relaxation response to ACh was partially inhibited by L-NAME but the remaining portion of the response was not attenuated further by indomethacin. However, treatment with the ET antagonist darusentan restored normal endothelial function [20], suggesting that endothelial NO, but not endotheliumderived prostanoids, mediates a portion of the relaxation response to $\mathrm{ACh}$ and this observation highlights the contribution of ET-1 to endothelial dysfunction. Thus, in the apoE $\mathrm{E}^{-1-}$ mouse, the major contribution to the endothelial dysfunction in resistance vessels appears to be from the increase in NADPH oxidase-derived $\cdot \mathrm{O}_{2}$ and ET-1.

\section{The balance between vasoconstrictor and vasodilator responsiveness in conducting and resistance vessels} Local vascular control depends on the balance between dilators and constrictors; thus vascular dysfunction, a term that is most often used to describe the impairment of endothelium NO-dependent vasodilatation, also involves changes in the vasoconstrictor response to endogenous and exogenous agents (see diagram in Figure 8). For local vascular control, the major opposition to vasodilator substances is ET-1 and this is in addition to Ang II from the renin-angiotensin system, which exists in the vascular endothelium [57]. In other species, hyperlipidemia has been associated with altered vasoconstrictor responsiveness in large arteries [111,112]. These studies demonstrated that vasoconstrictor responses to $\mathrm{NE}$ are increased in hypercholesterolemic rabbits and monkeys prior to their development of atherosclerosis. Arruda et al. [102] and Pereira et al. [103] showed that in mesenteric resistance arteries from male apoE ${ }^{-1-}$ mice fed a normal chow diet, vasoconstriction in response to norepinephrine was exacerbated despite a preserved vasodilation response to $\mathrm{ACh}$, which could be attributed to increased oxidative stress, as indicated by the finding that apocynin (a NADPH oxidase inhibitor) normalizes the increased vasoconstriction induced by the $\alpha_{1}$-adrenoceptor agonist phenylephrine

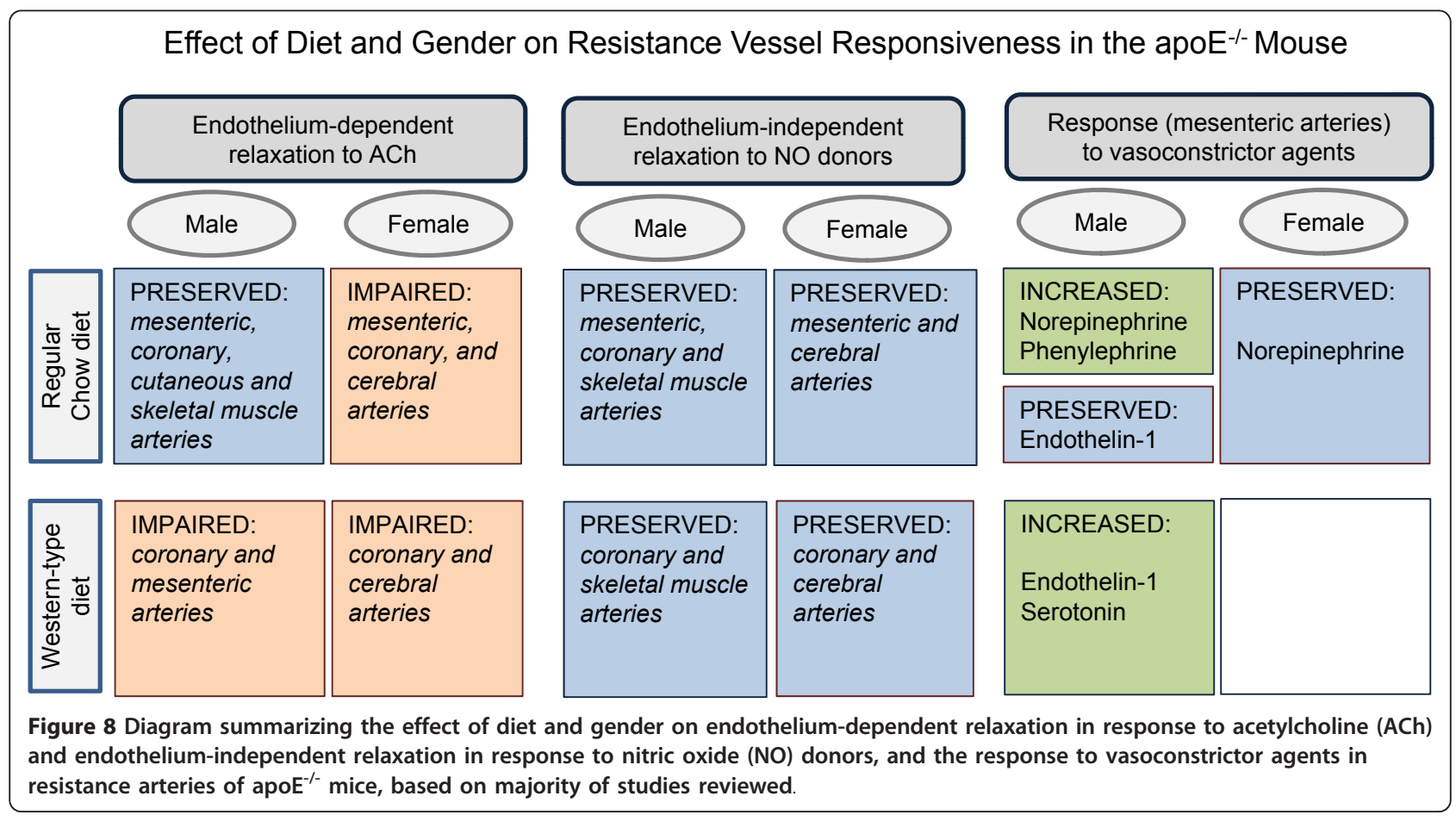


(PE) in hypercholesterolemic mice [86]. On the one hand, when fed a standard diet, $a p o E^{-1-}$ mice lesion-free thoracic aortas, which exhibit normal ACh-induced relaxations, exhibit an exacerbated sensitivity to PE, which is attributable to an attenuated basal bioavailability of $\mathrm{NO}$ [63]. On the other hand, young apoE $\mathrm{E}^{-/-}$mice fed a Western-type diet exhibit a normal aorta contractile response to PE but an augmented vasoconstrictor response to ET-1 [97]. However, when apoE $E^{-/-}$mice were fed a Western-type diet, which resulted in attenuation of the ACh-induced relaxation response in segments of the mesenteric arteries, increased levels of ET1 and enhanced contractions in response to ET- 1 and serotonin were observed [20]. In addition, the authors showed that treatment with the ET antagonist darusentan normalized the endothelium-dependent relaxation responses. Thus, the vascular dysfunction characterized by hyperresponsiveness of conducting and resistance vessels to $\alpha_{1}$-adrenoceptor agonists appears to be due to increased oxidative stress. The studies outlined above also suggest a remarkable contribution of the endogenous ET-1 peptide to endothelial dysfunction, primarily in resistance arteries.

The association of DNA damage with endothelial dysfunction and its treatment with new therapies A number of studies support the concept that there is a link between the ROS-induced oxidative damage to DNA in atherosclerosis and the overexpression of poly (ADP-ribose) polymerase (PARP) [113-116]. However, studies of the effects of acute and chronic PARP inhibition on the ability of the aorta to relax in response to $\mathrm{ACh}$ in apoE $\mathrm{E}^{-/-}$mice have produced conflicting conclusions. Pacher et al. [70] reported that the activation of PARP is associated with hypertension and aging, but not with atherosclerosis. In contrast, others [71,113] have shown that functional alterations in the endothelium, at least in the apoE $\mathrm{E}^{-/-}$mouse, are dependent on the activation of PARP in endothelial cells. Excessive oxidative stress and DNA damage have also been associated with vascular senescence, which was originally described as the limited ability of a cell to divide, and this could contribute to the pathogenesis of age-associated vascular disorders $[117,118]$. However, recent studies in our laboratory showed that, at least in the aorta, vascular senescence is present in atherosclerotic aged apoE $E^{-/-}$ mice but not in non-atherosclerotic aged wild-type C57mice [119], indicating that the occurrence of vascular senescence in aging needs to be associated with a vascular disease. The findings that vascular endothelial cells with senescence-associated phenotypes are present in human atherosclerotic lesions [120] and in atherosclerotic aged apoE ${ }^{-/-}$mice [119] leads us to hypothesize

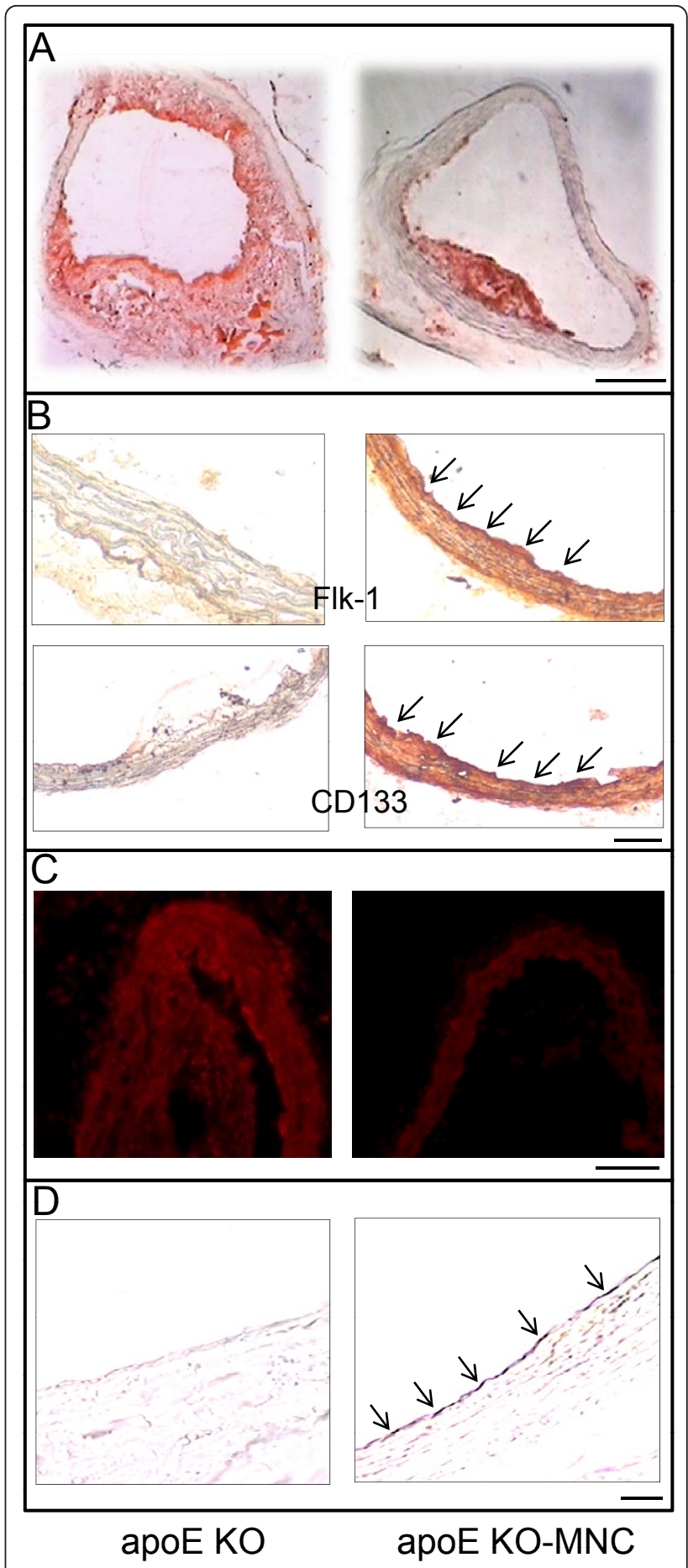

Figure 9 Representative photomicrographs showing the effect of mononuclear cell (MNC) therapy on (A) lipid deposition (OilRed-O staining), (B) homing of endothelial progenitor cells (stained with markers Flk-1 for vascular endothelial growth factor receptor and CD133 for hematopoietic stem cell antigen), (C) superoxide anion production (dihydroethidium staining), and (D) eNOS production (DAB staining) in the aortas of female apoE KO mice. Bar: $100 \mu \mathrm{m}(A)$ and $50 \mu \mathrm{m}$ (B, C and D). Reproduced with permission from Porto et al. [124]. 
that the senescence of vascular endothelial cells may be involved in endothelial dysfunction. The first evidence of this arises from the observation that the induction of senescence in human aortic endothelial cells by inhibiting telomere function results in decrease in eNOS activity $[120,121]$. Thus, the apoE $E^{-/-}$mouse model offers an opportunity to examine and understand the interaction of vascular endothelial dysfunction and senescence that is associated with the pathogenesis of atherosclerosis. However, there is consistent evidence [122], that the atherosclerotic process initiated by endothelial death in specific areas results in their subsequent replacement by endothelial progenitor cells and that cellular repair by progenitor cells of ongoing vascular injury may be important for vascular integrity and function. Indeed, treatment with spleen-derived mononuclear cells increases vascular NOS activity and restores endothelium-dependent relaxation in the aorta of apoE $E^{-/-}$mice [123]. This effect could be explained by our recent observation [124] that mononuclear cell therapy in apoE $^{-/-}$mice results in the homing of endothelial progenitor cells, a decrease in oxidative stress and an upregulation of eNOS expression (Figure 9). Therefore, cell therapy is a promising tool for the restoration of endothelial function and prevention of atherosclerosis development. Interestingly, a recent report [125] shows that sildenafil, a PDE5 inhibitor that increase NO-driven cGMP levels (see scheme in Figure 3), increases the number of bone marrow-derived endothelial progenitor cells and improves ischemia-induced neovascularization in hypercholesterolemic apoE ${ }^{-/-}$mice. The results of this pharmacological therapy [125] and other cell therapy $[123,124]$ studies in the apoE $E^{-/-}$mouse supports ongoing studies in our laboratory, in which both therapies are associated with the purpose to obtain a better improvement of endothelial function in this murine model of hypercholesterolemia and atherosclerosis.

\section{Conclusion}

Since its creation two decades ago, the apoE $E^{-/-}$mouse, which spontaneously develops hypercholesterolemia and vascular atherosclerotic lesions even when fed a regular chow diet, has provided us with excellent opportunities for investigating the role of apoE in lipid metabolism and to the disease process of atherosclerosis. In this review, we show that the influence of gender on the

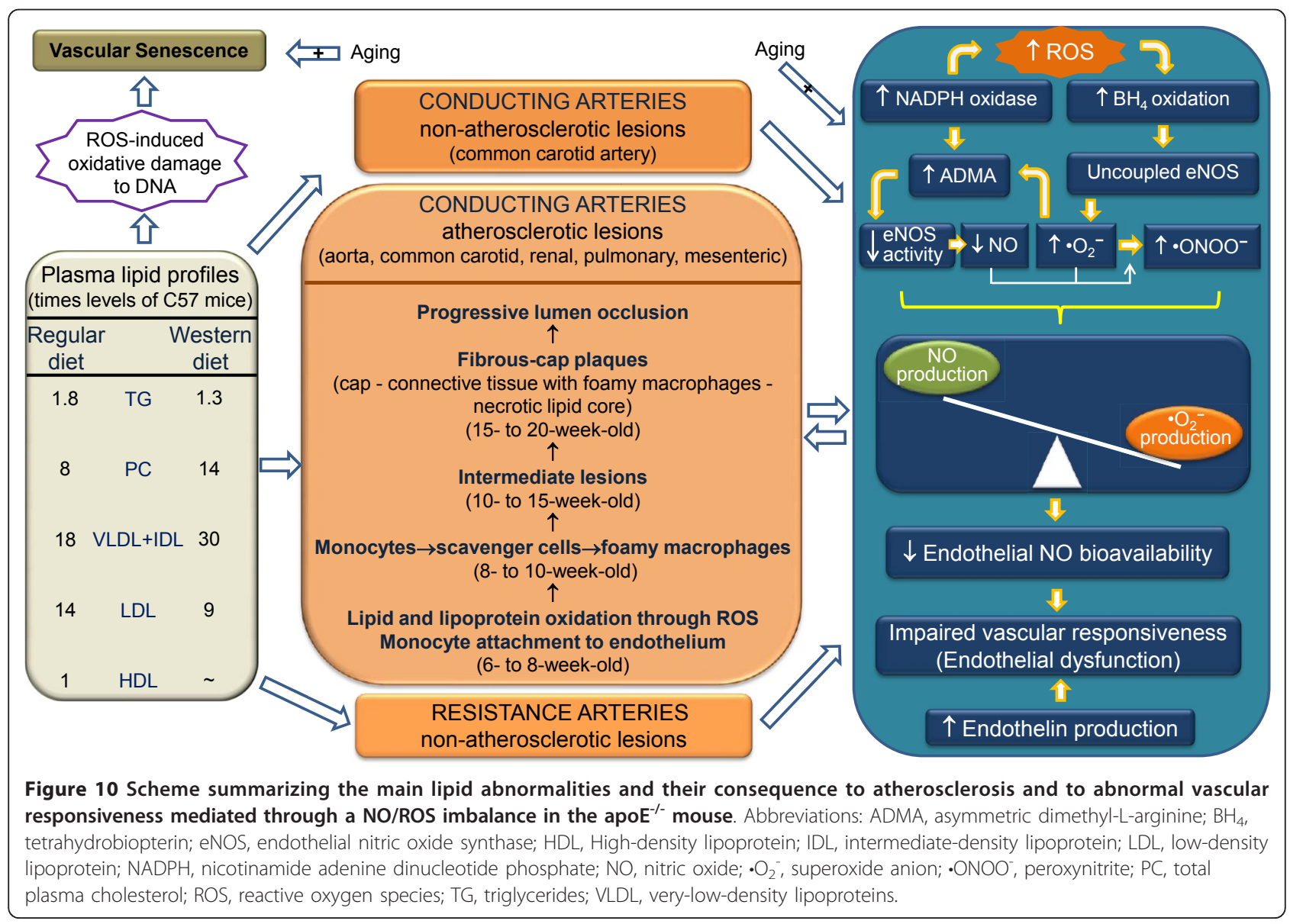


development of atherosclerotic lesions is controversial, but evidence of the detrimental effects of estrogen on atherosclerosis has emerged during the last decade. Thus, the influence of female gender, associated with age and type of diet, on atherosclerotic lesions and endothelial dysfunction in the apo: $\mathrm{E}^{-1-}$ mouse are expected to be subject of intense research. Several studies provide unquestionable evidence of endothelial dysfunction in conducting and resistance vessels in the apo: $\mathrm{E}^{-/-}$mouse. Most of these studies show that at the early stages of the disease, aortas retain their normal endothelial function but at the later stages of the disease and when mice are fed a Western-type diet, conducting vessels exhibit focal (plaque related) impairment of endothelial NO-mediated dilation. The dysfunction of the large vessels in this murine model is mainly a result of the reduced bioavailability of NO due to decreased eNOS activity and/or the chemical inactivation of $\mathrm{NO}$ by $\cdot \mathrm{O}_{2}{ }^{-}$, and the activation of the ET-1 system. In resistance vessels, the major contribution to the endothelial dysfunction appears to be an increase in NADPH oxidase-derived $\cdot \mathrm{O}_{2}{ }^{-}$, EDHF and ET-1. Despite the lack of studies focusing specifically on the influence of gender on endothelial dysfunction in apo $\mathrm{E}^{-/-}$ mice, there is some evidence that endothelial dysfunction in both conducting and resistance vessels is influenced by gender, aging and a Western-type diet. Scheme in Figure 10 summarizes the main lipid abnormalities and their consequence to atherosclerosis and to abnormal vascular responsiveness mediated through a NO/ROS imbalance in the apoE $\mathrm{E}^{-1-}$ mouse. From a clinical perspective, as the mechanisms involved in the vascular reduction in $\mathrm{NO}$ bioavailability and the excessive production of ROS become clear, more specific therapies to prevent this defect will be developed that will ultimately lead to the correction of endothelial dysfunction. In particular, studies investigating the use of cell therapy to restore vascular function constitute a promising avenue of research.

\section{Acknowledgements}

ECV and SSM are supported by the National Council for the Development of Science and Technology (CNPq, Ref. 302113/2008-8 and 302535/2009-8 Grants) and the State Agency for the Development of Science and Technology (FAPES, Ref. FAPES/PRONEX 012/2009). The critical comments from Mark W. Chapleau (The University of lowa) to the schematic representation of the mechanisms underlying endothelial dysfunction are much appreciated.

\section{Author details \\ 'Departament of Physiological Sciences, Health Sciences Center, Federal University of Espirito Santo, Vitoria, ES, Brazil. ${ }^{2}$ The University of lowa, lowa City, IA, USA. ${ }^{3}$ Federal Institute of Education, Science and Technology (IFES), Vila Velha, ES, Brazil. ${ }^{4}$ Emescam School of Health Sciences, Vitoria, ES, Brazil.}

\section{Authors' contributions}

ECV, VAP, TMCP and SSM contributed equally to the conception and preparation of this review. All authors read and approved the final manuscript.

\section{Competing interests}

The authors declare that they have no competing interests.

Received: 22 October 2011 Accepted: 14 November 2011 Published: 14 November 2011

\section{References}

1. Breslow JL: Transgenic mouse models of lipoprotein metabolism and atherosclerosis. Proc Natl Acad Sci USA 1993, 90(18):8314-8.

2. Piedrahita JA, Zhang SH, Hagaman JR, Oliver PM, Maeda N: Generation of mice carrying a mutant apolipoprotein $\mathrm{E}$ gene inactivated by gene targeting in embryonic stem cells. Proc Natl Acad Sci USA 1992, 89(10):4471-5.

3. Plump AS, Smith JD, Hayek T, Aalto-Setälä K, Walsh A, Verstuyft JG, Rubin EM, Breslow JL: Severe hypercholesterolemia and atherosclerosis in apolipoprotein E-deficient mice created by homologous recombination in ES cells. Cell 1992, 71(2):343-53.

4. Deckert V, Lizard G, Duverger N, Athias A, Palleau V, Emmanuel F, Moisant M, Gambert P, Lallemant C, Lagrost L: Impairment of endothelium-dependent arterial relaxation by high-fat feeding in ApoEdeficient mice: toward normalization by human ApoA-I expression. Circulation 1999, 100(11):1230-5.

5. Kuhlencordt PJ, Gyurko R, Han F, Scherrer-Crosbie M, Aretz TH, Hajjar R, Picard MH, Huang PL: Accelerated atherosclerosis, aortic aneurysm formation, and ischemic heart disease in apolipoprotein E/endothelial nitric oxide synthase double-knockout mice. Circulation 2001, 104(4):448-54.

6. Kaul S, Coin B, Hedayiti A, Yano J, Cercek B, Chyu KY, Shah PK: Rapid reversal of endothelial dysfunction in hypercholesterolemic apolipoprotein E-null mice by recombinant apolipoprotein A-I (Milano)phospholipid complex. J Am Coll Cardiol 2004, 44(6):1311-9.

7. Wassmann S, Czech T, van Eickels M, Fleming I, Böhm M, Nickenig G: Inhibition of diet-induced atherosclerosis and endothelial dysfunction in apolipoprotein E/angiotensin II type $1 \mathrm{~A}$ receptor double-knockout mice. Circulation 2004, 110(19):3062-7.

8. Ohashi M, Runge MS, Faraci FM, Heistad DD: MnSOD deficiency increases endothelial dysfunction in ApoE-deficient mice. Arterioscler Thromb Vasc Biol 2006, 26(10):2331-6.

9. Jawień J, NastaŃek P, Korbut R: Mouse models of experimental atherosclerosis. J Physiol Pharmacol 2004, 55(3):503-17.

10. Meir KS, Leitersdorf E: Atherosclerosis in the apolipoprotein-E-deficient mouse: a decade of progress. Arterioscler Thromb Vasc Biol 2004, 24(6):1006-14.

11. Zhang SH, Reddick RL, Piedrahita JA, Maeda N: Spontaneous hypercholesterolemia and arterial lesions in mice lacking apolipoprotein E. Science 1992, 258(5081):468-71.

12. Bonthu S, Heistad DD, Chappell DA, Lamping KG, Faraci FM: Atherosclerosis, vascular remodeling, and impairment of endotheliumdependent relaxation in genetically altered hyperlipidemic mice. Arterioscler Thromb Vasc Biol 1997, 17(11):2333-40.

13. Paigen B, Morrow A, Holmes PA, Mitchell D, Williams RA: Quantitative assessment of atherosclerotic lesions in mice. Atherosclerosis 1987, 68(3):231-40.

14. Paigen B, Holmes PA, Mitchell D, Albee D: Comparison of atherosclerotic lesions and $\mathrm{HDL}$-lipid levels in male, female, and testosterone-treated female mice from strains C57BL/6, BALB/C, and C3H. Atherosclerosis 1987, 64(2-3):215-21.

15. Mahley RW: Apolipoprotein E: cholesterol transport protein with expanding role in cell biology. Science 1988, 240(4852):622-30.

16. Stapleton PA, Goodwill AG, James ME, Frisbee JC: Altered mechanisms of endothelium-dependent dilation in skeletal muscle arterioles with genetic hypercholesterolemia. Am J Physiol Regul Integr Comp Physiol 2007, 293(3):R1110-9.

17. Lee MY, Li H, Xiao Y, Zhou Z, Xu A, Vanhoutte PM: Chronic administration of BMS309403 improves endothelial function in apolipoprotein Edeficient mice and in cultured human endothelial cells. Br J Pharmacol 2011, 162(7):1564-76

18. Zhang SH, Reddick RL, Burkey B, Maeda N: Diet-induced atherosclerosis in mice heterozygous and homozygous for apolipoprotein $\mathrm{E}$ gene disruption. J Clin Invest 1994, 94(3):937-45 
19. Niebauer J, Maxwell AJ, Lin PS, Tsao PS, Kosek J, Bernstein D, Cooke JP: Impaired aerobic capacity in hypercholesterolemic mice: partial reversal by exercise training. Am J Physiol 1999, 276(4 Pt 2):H1346-54.

20. d'Uscio LV, Barton M, Shaw S, Lüscher TF: Chronic ET (A) receptor blockade prevents endothelial dysfunction of small arteries in apolipoprotein Edeficient mice. Cardiovasc Res 2002, 53(2):487-95.

21. Surra JC, Guillén N, Arbonés-Mainar JM, Barranquero C, Navarro MA, Arnal C, Orman I, Segovia JC, Osada J: Sex as a profound modifier of atherosclerotic lesion development in apolipoprotein E-deficient mice with different genetic backgrounds. J Atheroscler Thromb 2010, 17(7):712-21

22. Jiang F, Gibson AP, Dusting GJ: Endothelial dysfunction induced by oxidized low-density lipoproteins in isolated mouse aorta: a comparison with apolipoprotein-E deficient mice. Eur J Pharmacol 2001, 424(2):141-9.

23. Gervais M, Pons S, Nicoletti A, Cosson C, Giudicelli JF, Richer C: Fluvastatin prevents renal dysfunction and vascular NO deficit in apolipoprotein Edeficient mice. Arterioscler Thromb Vasc Biol 2003, 23(2):183-9.

24. Smith DD, Tan X, Tawfik O, Milne G, Stechschulte DJ, Dileepan KN: Increased aortic atherosclerotic plaque development in female apolipoprotein E-null mice is associated with elevated thromboxane $A_{2}$ and decreased prostacyclin production. J Physiol Pharmacol 2010, 61(3):309-16.

25. Nakashima Y, Plump AS, Raines EW, Breslow JL, Ross R: ApoE-deficient mice develop lesions of all phases of atherosclerosis throughout the arterial tree. Arterioscler Thromb 1994, 14(1):133-40.

26. Coleman R, Hayek T, Keidar S, Aviram M: A mouse model for human atherosclerosis: long-term histopathological study of lesion development in the aortic arch of apolipoprotein $\mathrm{E}$-deficient $\left(\mathrm{E}^{0}\right)$ mice. Acta Histochem 2006, 108(6):415-24.

27. Yamashita T, Kawashima S, Ozaki M, Namiki M, Shinohara M, Inoue N, Hirata K, Umetani K, Yokoyama M: In vivo angiographic detection of vascular lesions in apolipoprotein E-knockout mice using a synchrotron radiation microangiography system. Circ J 2002, 66(11):1057-9.

28. Pérez-López FR, Larrad-Mur L, Kallen A, Chedraui P, Taylor HS: Gender differences in cardiovascular disease: hormonal and biochemical influences. Reprod Sci 2010, 17(6):511-31.

29. Thomas CM, Smart EJ: Gender as a regulator of atherosclerosis in murine models. Curr Drug Targets 2007, 8:1172-80.

30. Tangirala RK, Rubin EM, Palinski W: Quantitation of atherosclerosis in murine models: correlation between lesions in the aortic origin and in the entire aorta, and differences in the extent of lesions between sexes in $L D L$ receptor-deficient and apolipoprotein E-deficient mice. J Lipid Res 1995, 36(11):2320-8.

31. Elhage R, Arnal JF, Pieraggi MT, Duverger N, Fiévet C, Faye JC, Bayard F: 17 beta-estradiol prevents fatty streak formation in apolipoprotein Edeficient mice. Arterioscler Thromb Vasc Biol 1997, 17(11):2679-84.

32. Chiba T, Ikeda M, Umegaki K, Tomita T: Estrogen-dependent activation of neutral cholesterol ester hydrolase underlying gender difference of atherogenesis in apoE ${\left({ }^{-/}\right)}^{-}$mice. Atherosclerosis 2011.

33. Bourassa PA, Milos PM, Gaynor BJ, Breslow JL, Aiello RJ: Estrogen reduces atherosclerotic lesion development in apolipoprotein E-deficient mice. Proc Natl Acad Sci USA 1996, 93(19):10022-7.

34. Grey AB, Stapleton JP, Evans MC, Reid IR: The effect of the anti-estrogen tamoxifen on cardiovascular risk factors in normal postmenopausal women. J Clin Endocrinol Metab 1995, 80(11):3191-5.

35. Reckless J, Metcalfe JC, Grainger DJ: Tamoxifen decreases cholesterol sevenfold and abolishes lipid lesion development in apolipoprotein $\mathrm{E}$ knockout mice. Circulation 1997, 95(6):1542-8.

36. Caligiuri G, Nicoletti A, Zhou X, Törnberg I, Hansson GK: Effects of sex and age on atherosclerosis and autoimmunity in apoE-deficient mice. Atherosclerosis 1999, 145(2):301-8.

37. Freudenberger T, Oppermann M, Heim HK, Mayer P, Kojda G, Schrör K, Fischer JW: Proatherogenic effects of estradiol in a model of accelerated atherosclerosis in ovariectomized ApoE-deficient mice. Basic Res Cardiol 2010, 105(4):479-86.

38. Maeda N, Johnson L, Kim S, Hagaman J, Friedman M, Reddick R: Anatomical differences and atherosclerosis in apolipoprotein E-deficient mice with $129 / \mathrm{SvEv}$ and $\mathrm{C} 57 \mathrm{BL} / 6$ genetic backgrounds. Atherosclerosis 2007, 195(1):75-82.

39. Davignon J, Ganz P: Role of endothelial dysfunction in atherosclerosis. Circulation 2004, 109(23 Suppl 1):III27-32.
40. Harrison DG: Endothelial dysfunction in atherosclerosis. Basic Res Cardiol 1994, 89(Suppl1):87-102.

41. Landmesser U, Hornig B, Drexler H: Endothelial function: a critical determinant in atherosclerosis? Circulation 2004, 109(21 Suppl 1):|127-33.

42. Katusic ZS: Vascular endothelial dysfunction: does tetrahydrobiopterin play a role? Am J Physiol Heart Circ Physiol 2001, 281(3):H981-6.

43. Ray R, Shah AM: NADPH oxidase and endothelial cell function. Clin SCi (Lond) 2005, 109(3):217-26.

44. Lassègue $B$, Griendling KK: NADPH oxidases: Functions and pathologies in the vasculature. Arterioscler Thromb Vasc Biol 2010, 30(4):653-61.

45. Sirker A, Zhang M, Shah AM: NADPH oxidases in cardiovascular disease: insights from in vivo models and clinical studies. Basic Res Cardiol 2011, 106(5):735-47.

46. Fukai T, Ushio-Fukai M: Superoxide Dismutases: role in redox signaling, vascular function, and diseases. Antioxid Redox Signal 2011, 15(6):1583-606.

47. Busse R, Edwards G, Félétou M, Fleming I, Vanhoutte PM, Weston AH: EDHF: bringing the concepts together. Trends Pharmacol Sci 2001, 23(8):374-80.

48. Shimokawa $H$, Matoba T: Hydrogen peroxide as an endothelium-derived hyperpolarizing factor. Pharmacol Res 2004, 49(6):543-9.

49. Ardanaz N, Pagano PJ: Hydrogen peroxide as a paracrine vascular mediator: regulation and signaling leading to dysfunction. Exp Biol Med (Maywood) 2006, 231(3):237-51

50. Touyz RM, Briones AM: Reactive oxygen species and vascular biology: implications in human hypertension. Hypertens Res 2011, 34(1):5-14.

51. Zembowicz A, Hatchett RJ, Jakubowski AM, Gryglewski RJ: Involvement of nitric oxide in the endothelium-dependent relaxation induced by hydrogen peroxide in the rabbit aorta. Br J Pharmacol 1993, 110(1):151-8.

52. Capettini LS, Cortes SF, Gomes MA, Silva GA, Pesquero JL, Lopes MJ, Teixeira MM, Lemos VS: Neuronal nitric oxide synthase-derived hydrogen peroxide is a major endothelium-dependent relaxing factor. Am J Physiol Heart Circ Physiol 2008, 295(6):H2503-11.

53. Thengchaisri N, Kuo L: Hydrogen peroxide induces endotheliumdependent and -independent coronary arteriolar dilation: role of cyclooxygenase and potassium channels. Am J Physiol Heart Circ Physiol 2003, 285(6):H2255-63.

54. Matoba T, Shimokawa H, Nakashima M, Hirakawa Y, Mukai Y, Hirano K, Kanaide $H$, Takeshita A: Hydrogen peroxide is an endothelium-derived hyperpolarizing factor in mice. J Clin Invest 2000, 106(12):1521-30.

55. Cai H: Hydrogen peroxide regulation of endothelial function: origins, mechanisms, and consequences. Cardiovasc Res 2005, 68(1):26-36.

56. Félétou M, Vanhoutte PM: EDHF: an update. Clin Sci (Lond) 2009, 117(4):139-55.

57. Anderson TJ: Assessment and treatment of endothelial dysfunction in humans. J Am Coll Cardiol 1999, 34(3):631-8.

58. Cai H, Harrison DG: Endothelial dysfunction in cardiovascular diseases: the role of oxidant stress. Circ Res 2000, 87(10):840-4.

59. Félétou M, Vanhoutte PM: Endothelial dysfunction: a multifaceted disorder (The Wiggers Award Lecture). Am J Physiol Heart Circ Physiol 2006, 291(3):H985-1002.

60. Simonsen U, Rodriguez-Rodriguez R, Dalsgaard T, Buus NH, Stankevicius E: Novel approaches to improving endothelium-dependent nitric oxidemediated vasodilatation. Pharmacol Rep 2009, 61(1):105-15.

61. Ross R: Rous-Whipple Award Lecture. Atherosclerosis: a defense mechanism gone awry. Am J Pathol 1993, 143(4):987-1002.

62. Wang $Y X$, Halks-Miller M, Vergona R, Sullivan ME, Fitch $R$, Mallari $C$, MartinMcNulty B, da Cunha V, Freay A, Rubanyi GM, Kauser K: Increased aortic stiffness assessed by pulse wave velocity in apolipoprotein E-deficient mice. Am J Physiol Heart Circ Physiol 2000, 278(2):H428-34.

63. Fransen P, Van Assche T, Guns PJ, Van Hove CE, De Keulenaer GW, Herman AG, Bult $H$ : Endothelial function in aorta segments of apolipoprotein E-deficient mice before development of atherosclerotic lesions. Pflugers Arch 2008, 455(5):811-8.

64. Villeneuve N, Fortuno A, Sauvage M, Fournier N, Breugnot C, Jacquemin C, Petit C, Gosgnach W, Carpentier N, Vanhoutte P, Vilaine JP: Persistence of the nitric oxide pathway in the aorta of hypercholesterolemic apolipoprotein-E-deficient mice. J Vasc Res 2003, 40(2):87-96.

65. Yaghoubi M, Oliver-Krasinski J, Cayatte AJ, Cohen RA: Decreased sensitivity to nitric oxide in the aorta of severely hypercholesterolemic apolipoprotein E-deficient mice. J Cardiovasc Pharmacol 2000, 36(6):751-7. 
66. Crauwels HM, Van Hove CE, Holvoet P, Herman AG, Bult H: Plaqueassociated endothelial dysfunction in apolipoprotein E-deficient mice on a regular diet. Effect of human apolipoprotein Al. Cardiovasc Res 2003 59(1):189-99.

67. Guns PJ, Van Assche T, Verreth W, Fransen P, Mackness B, Mackness M, Holvoet $P$, Bult $H$ : Paraoxonase 1 gene transfer lowers vascular oxidative stress and improves vasomotor function in apolipoprotein E-deficient mice with pre-existing atherosclerosis. Br J Pharmacol 2008, 153(3):508-16.

68. Barton M, Haudenschild CC, d'Uscio LV, Shaw S, Münter K, Lüscher TF: Endothelin $\mathrm{ET}_{\mathrm{A}}$ receptor blockade restores NO-mediated endothelial function and inhibits atherosclerosis in apolipoprotein E-deficient mice. Proc Natl Acad Sci USA 1998, 95(24):14367-72.

69. d'Uscio LV, Baker TA, Mantilla CB, Smith L, Weiler D, Sieck GC, Katusic ZS Mechanism of endothelial dysfunction in apolipoprotein E-deficient mice. Arterioscler Thromb Vasc Biol 2001, 21(6):1017-22.

70. Pacher P, Mabley JG, Soriano FG, Liaudet L, Szabó C: Activation of poly (ADP-ribose) polymerase contributes to the endothelial dysfunction associated with hypertension and aging. Int J Mol Med 2002, 9(6):659-64

71. Benkö R, Pacher P, Vaslin A, Kollai M, Szabó C: Restoration of the endothelial function in the aortic rings of apolipoprotein $E$ deficient mice by pharmacological inhibition of the nuclear enzyme poly(ADPribose) polymerase. Life Sci 2004, 75(10):1255-61.

72. Mujynya-Ludunge $K$, Viswambharan $H$, Driscoll $R$, Ming XF, von Segesser LK, Kappenberger L, Yang Z, Vassalli G: Endothelial nitric oxide synthase gene transfer restores endothelium-dependent relaxations and attenuates lesion formation in carotid arteries in apolipoprotein E-deficient mice. Basic Res Cardiol 2005, 100(2):102-11.

73. Pellegrin M, Berthelot A, Houdayer C, Gaume V, Deckert V, Laurant P: New insights into the vascular mechanisms underlying the beneficial effect of swimming training on the endothelial vasodilator function in apolipoprotein E-deficient mice. Atherosclerosis 2007, 190(1):35-42.

74. Custodis F, Baumhäkel M, Schlimmer N, List F, Gensch C, Böhm M, Laufs U: Heart rate reduction by ivabradine reduces oxidative stress, improves endothelial function, and prevents atherosclerosis in apolipoprotein Edeficient mice. Circulation 2008, 117(18):2377-87.

75. Vinh A, Widdop RE, Drummond GR, Gaspari TA: Chronic angiotensin IV treatment reverses endothelial dysfunction in ApoE-deficient mice. Cardiovasc Res 2008, 77(1):178-87.

76. Tesanovic S, Vinh A, Gaspari TA, Casley D, Widdop RE: Vasoprotective and atheroprotective effects of angiotensin (1-7) in apolipoprotein Edeficient mice. Arterioscler Thromb Vasc Biol 2010, 30(8):1606-13.

77. Johansson ME, Hägg U, Wikström J, Wickman A, Bergström G, Gan LM: Haemodynamically significant plaque formation and regional endothelial dysfunction in cholesterol-fed ApoE-/- mice. Clin Sci (Lond) 2005, 108(6):531-8

78. Kuhn FE, Mohler ER, Satler LF, Reagan K, Lu DY, Rackley CE: Effects of highdensity lipoprotein on acetylcholine-induced coronary vasoreactivity. Am J Cardiol 1991, 68(15):1425-30.

79. Raman KG, Gandley RE, Rohland J, Zenati MS, Tzeng E: Early hypercholesterolemia contributes to vasomotor dysfunction and injury associated atherogenesis that can be inhibited by nitric oxide. J Vasc Surg 2011, 53(3):754-63.

80. d'Uscio LV, Smith LA, Katusic ZS: Hypercholesterolemia impairs endothelium-dependent relaxations in common carotid arteries of apolipoprotein E-deficient mice. Stroke 2001, 32(11):2658-64.

81. Böhm F, Ahlborg G, Pernow J: Endothelin-1 inhibits endotheliumdependent vasodilatation in the human forearm: reversal by ETA receptor blockade in patients with atherosclerosis. Clin Sci (Lond) 2002 , 102(3):321-7.

82. Stroes E, Kastelein J, Cosentino F, Erkelens W, Wever R, Koomans H, Lüscher T, Rabelink T: Tetrahydrobiopterin restores endothelial function in hypercholesterolemia. J Clin Invest 1997, 99(1):41-6.

83. Laursen JB, Somers M, Kurz S, McCann L, Warnholtz A, Freeman BA Tarpey M, Fukai T, Harrison DG: Endothelial regulation of vasomotion in apoE-deficient mice: implications for interactions between peroxynitrite and tetrahydrobiopterin. Circulation 2001, 103(9):1282-8.

84. Barry-Lane PA, Patterson C, van der Merwe M, Hu Z, Holland SM, Yeh ET, Runge MS: p47phox is required for atherosclerotic lesion progression in ApoE $\left(^{-1-}\right)$ mice. J Clin Invest 2001, 108(10):1513-22.

85. Laufs U, Wassmann $\mathrm{S}$, Czech $T$, Münzel T, Eisenhauer $\mathrm{M}$, Böhm $\mathrm{M}$, Nickenig G: Physical inactivity increases oxidative stress, endothelial dysfunction, and atherosclerosis. Arterioscler Thromb Vasc Biol 2005, 25(4):809-14

86. Matsumoto T, Miyamori K, Kobayashi T, Kamata K: Apocynin normalizes hyperreactivity to phenylephrine in mesenteric arteries from cholesterolfed mice by improving endothelium-derived hyperpolarizing factor response. Free Radic Biol Med 2006, 41(8):1289-303.

87. Jiang F, Guo Y, Salvemini D, Dusting GJ: Superoxide dismutase mimetic M40403 improves endothelial function in apolipoprotein(E)-deficient mice. Br J Pharmacol 2003, 139(6):1127-34

88. Daugherty A, Rateri DL, Lu H, Inagami T, Cassis LA: Hypercholesterolemia stimulates angiotensin peptide synthesis and contributes to atherosclerosis through the $\mathrm{AT}_{1 \mathrm{~A}}$ receptor. Circulation 2004, 110(25):3849-57

89. Arakawa $\mathrm{K}$, Urata $\mathrm{H}$ : Hypothesis regarding the pathophysiological role of alternative pathways of angiotensin II formation in atherosclerosis. Hypertension 2000, 36(4):638-41.

90. Wolf G: Free radical production and angiotensin. Curr Hypertens Rep 2000, 2(2):167-73.

91. Weiss D, Kools JJ, Taylor WR: Angiotensin II-induced hypertension accelerates the development of atherosclerosis in apoE-deficient mice. Circulation 2001, 103(3):448-54

92. Tham DM, Martin-McNulty B, Wang YX, Da Cunha V, Wilson DW, Athanassious CN, Powers AF, Sullivan ME, Rutledge JC: Angiotensin II injures the arterial wall causing increased aortic stiffening in apolipoprotein E-deficient mice. Am J Physiol Regul Integr Comp Physiol 2002, 283(6):R1442-9.

93. Mazzolai L, Duchosal MA, Korber M, Bouzourene K, Aubert JF, Hao H, Vallet V, Brunner HR, Nussberger J, Gabbiani G, Hayoz D: Endogenous angiotensin II induces atherosclerotic plaque vulnerability and elicits a Th1 response in $\mathrm{ApoE}^{-/-}$mice. Hypertension 2004, 44(3):277-82.

94. Warnholtz A, Nickenig G, Schulz E, Macharzina R, Bräsen JH, Skatchkov M, Heitzer T, Stasch JP, Griendling KK, Harrison DG, Böhm M, Meinertz T, Münzel T: Increased NADH-oxidase-mediated superoxide production in the early stages of atherosclerosis: evidence for involvement of the renin-angiotensin system. Circulation 1999, 99(15):2027-33.

95. Williams KJ, Scalia R, Mazany KD, Rodrigueza W, Lefer AM: Rapid restoration of normal endothelial functions in genetically hyperlipidemic mice by a synthetic mediator of reverse lipid transport. Arterioscler Thromb Vasc Biol 2000, 20(4):1033-9.

96. Pelat M, Dessy C, Massion P, Desager JP, Feron O, Balligand IL: Rosuvastatin decreases caveolin-1 and improves nitric oxide-dependent heart rate and blood pressure variability in apolipoprotein E-/- mice in vivo. Circulation 2003, 107(19):2480-6.

97. Maguire JJ, Wiley KE, Kuc RE, Stoneman VE, Bennett MR, Davenport AP: Endothelin-mediated vasoconstriction in early atherosclerosis is markedly increased in $\mathrm{ApoE}^{-/-}$mouse but prevented by atorvastatin. Exp Biol Med (Maywood) 2006, 231(6):806-12.

98. Cheng C, Tempel D, Oostlander A, Helderman F, Gijsen F, Wentzel J, van Haperen R, Haitsma DB, Serruys PW, van der Steen AF, de Crom R, Krams R: Rapamycin modulates the eNOS vs. shear stress relationship. CardiovasC Res 2008, 78(1):123-9.

99. Gadioli AL, Nogueira BV, Arruda RM, Pereira RB, Meyrelles SS, Arruda JA, Vasquez EC: Oral rapamycin attenuates atherosclerosis without affecting the arterial responsiveness of resistance vessels in apolipoprotein Edeficient mice. Braz J Med Biol Res 2009, 42(12):1191-5.

100. Zeiher AM, Drexler $H$, Wollschläger $H$, Just $H$ : Endothelial dysfunction of the coronary microvasculature is associated with coronary blood flow regulation in patients with early atherosclerosis. Circulation 1991, 84(5):1984-92.

101. Yang R, Powell-Braxton L, Ogaoawara AK, Dybdal N, Bunting S, Ohneda O, Jin $\mathrm{H}$ : Hypertension and endothelial dysfunction in apolipoprotein $\mathrm{E}$ knockout mice. Arterioscler Thromb Vasc Biol 1999, 19(11):2762-8.

102. Arruda RM, Peotta VA, Meyrelles SS, Vasquez EC: Evaluation of vascular function in apolipoprotein E knockout mice with angiotensin-dependent renovascular hypertension. Hypertension 2005, 46(4):932-6.

103. Pereira RB, Vasquez EC, Stefanon I, Meyrelles SS: Oral P. gingivalis infection alters the vascular reactivity in healthy and spontaneously atherosclerotic mice. Lipids Health Dis 2011, 10:80.

104. Wölfle SE, de Wit C: Intact endothelium-dependent dilation and conducted responses in resistance vessels of hypercholesterolemic mice in vivo. J Vasc Res 2005, 42(6):475-82. 
105. Gödecke A, Ziegler M, Ding Z, Schrader J: Endothelial dysfunction of coronary resistance vessels in apoE ${ }^{-/-}$mice involves $\mathrm{NO}$ but not prostacyclin-dependent mechanisms. Cardiovasc Res 2002, 53(1):253-62.

106. Lamping KG, Nuno DW, Chappell DA, Faraci FM: Agonist-specific impairment of coronary vascular function in genetically altered, hyperlipidemic mice. Am J Physiol 1999, 276(4 Pt 2):R1023-9.

107. Xu X, Gao X, Potter BJ, Cao JM, Zhang C: Anti-LOX-1 rescues endothelial function in coronary arterioles in atherosclerotic ApoE knockout mice. Arterioscler Thromb Vasc Biol 2007, 27(4):871-7.

108. Cola MS, Gava AL, Meyrelles SS, Vasquez EC: Endothelial dysfunction of resistance vessels in female apolipoprotein E-deficient mice. Lipids Health Dis 2010, 9:51

109. Kitayama J, Faraci FM, Lentz SR, Heistad DD: Cerebral vascular dysfunction during hypercholesterolemia. Stroke 2007, 38(7):2136-41.

110. Brandes RP, Schmitz-Winnenthal FH, Félétou M, Gödecke A, Huang PL, Vanhoutte PM, Fleming I, Busse R: An endothelium-derived hyperpolarizing factor distinct from NO and prostacyclin is a major endothelium-dependent vasodilator in resistance vessels of wild-type and endothelial NO synthase knockout mice. Proc Natl Acad Sci USA 2000, 97(17):9747-52.

111. Yokoyama M, Akita H, Mizutani T, Fukuzaki H, Watanabe Y: Hyperreactivity of coronary arterial smooth muscles in response to ergonovine from rabbits with hereditary hyperlipidemia. Circ Res 1983, 53(1):63-71.

112. Heistad DD, Armstrong ML, Marcus ML, Piegors DJ, Mark AL: Augmented responses to vasoconstrictor stimuli in hypercholesterolemic and atherosclerotic monkeys. Circ Res 1984, 54(6):711-8.

113. Hans $C P$, Feng $Y$, Naura AS, Zerfaoui $M$, Rezk BM, Xia H, Kaye AD, Matrougui K, Lazartigues E, Boulares AH: Protective effects of PARP-1 knockout on dyslipidemia-induced autonomic and vascular dysfunction in ApoE mice: effects on eNOS and oxidative stress. PLoS One 2009, 4(10):e7430

114. Virág L, Szabó C: BCL-2 protects peroxynitrite-treated thymocytes from poly(ADP-ribose) synthase (PARS)-independent apoptotic but not from PARS-mediated necrotic cell death. Free Radic Biol Med 2000, 29(8):704-13.

115. Oumouna-Benachour K, Oumouna M, Zerfaoui M, Hans C, Fallon K, Boulares $\mathrm{AH}$ : Intrinsic resistance to apoptosis of colon epithelial cells is a potential determining factor in the susceptibility of the $A / J$ mouse strain to dimethylhydrazine-induced colon tumorigenesis. Mol Carcinog 2007, 46(12):993-1002.

116. Martinet W, Knaapen MW, De Meyer GR, Herman AG, Kockx MM: Elevated levels of oxidative DNA damage and DNA repair enzymes in human atherosclerotic plaques. Circulation 2002, 106(8):927-32.

117. Minamino T, Komuro I: Vascular cell senescence: contribution to atherosclerosis. Circ Res 2007, 100(1):15-26.

118. Ota $H$, Eto M, Ogawa S, lijima K, Akishita M, Ouchi Y: SIRT1/eNOS axis as a potential target against vascular senescence, dysfunction and atherosclerosis. J Atheroscler Thromb 2010, 17(5):431-5.

119. Pereira TM, Nogueira BV, Lima LC, Porto ML, Arruda JA, Vasquez EC, Meyrelles SS: Cardiac and vascular changes in elderly atherosclerotic mice: the influence of gender. Lipids Health Dis 2010, 9:87.

120. Minamino T, Miyauchi H, Yoshida T, Ishida Y, Yoshida H, Komuro I: Endothelial cell senescence in human atherosclerosis: role of telomere in endothelial dysfunction. Circulation 2002, 105(13):1541-4.

121. Matsushita H, Chang E, Glassford AJ, Cooke JP, Chiu CP, Tsao PS: eNOS activity is reduced in senescent human endothelial cells: Preservation by hTERT immortalization. Circ Res 2001, 89(9):793-8.

122. Xu Q: The impact of progenitor cells in atherosclerosis. Nat Clin Pract Cardiovasc Med 2006, 3(2):94-101.

123. Wassmann S, Werner N, Czech T, Nickenig G: Improvement of endothelial function by systemic transfusion of vascular progenitor cells. Circ Res 2006, 99(8):e74-83.

124. Porto ML, Lima LC, Pereira TM, Nogueira BV, Tonini CL, Campagnaro BP, Meyrelles SS, Vasquez EC: Mononuclear cell therapy attenuates atherosclerosis in apoE KO mice. Lipids Health Dis 2011, 10:155.

125. Dussault S, Maingrette F, Ménard C, Michaud S-E, Haddad P, Groleau J, Turgeon J. Perez G, Rivard A: Sildenafil increases endothelial progenitor cell function and improves ischemia-induced neovascularization in hypercholesterolemic apolipoprotein E-deficient mice. Hypertension 2009, 54:1043-49.
doi:10.1186/1476-511X-10-211

Cite this article as: Meyrelles et al:: Endothelial Dysfunction in the Apolipoprotein E-deficient Mouse: insights into the influence of diet, gender and aging. Lipids in Health and Disease 2011 10:211.

\section{Submit your next manuscript to BioMed Central and take full advantage of:}

- Convenient online submission

- Thorough peer review

- No space constraints or color figure charges

- Immediate publication on acceptance

- Inclusion in PubMed, CAS, Scopus and Google Scholar

- Research which is freely available for redistribution

Submit your manuscript at www.biomedcentral.com/submit
Ciomed Central 